\title{
ROS and NO Phytomelatonin-Induced Signaling Mechanisms under Metal Toxicity in Plants: A Review
}

\author{
Miriam Pardo-Hernández, María López-Delacalle ${ }^{D}$, José Manuel Martí-Guillen (D), Sara E. Martínez-Lorente and \\ Rosa M. Rivero *(D)
}

Citation: Pardo-Hernández, M.; López-Delacalle, M.; Martí-Guillen, J.M.; Martínez-Lorente, S.E.; Rivero, R.M. ROS and NO PhytomelatoninInduced Signaling Mechanisms under Metal Toxicity in Plants: A Review. Antioxidants 2021, 10, 775. https:// doi.org/10.3390/antiox10050775

Academic Editor: Gaia Favero

Received: 23 April 2021

Accepted: 11 May 2021

Published: 13 May 2021

Publisher's Note: MDPI stays neutral with regard to jurisdictional claims in published maps and institutional affiliations.

Copyright: (c) 2021 by the authors. Licensee MDPI, Basel, Switzerland. This article is an open access article distributed under the terms and conditions of the Creative Commons Attribution (CC BY) license (https:/ / creativecommons.org/licenses/by/ $4.0 /)$.
Center of Edaphology and Applied Biology of Segura River-Spanish National Research Council (CEBAS-CSIC), Department of Plant Nutrition, Campus Universitario Espinardo, Ed. 25, 30100 Espinardo, Murcia, Spain; mpardo@cebas.csic.es (M.P.-H.); mlopez@cebas.csic.es (M.L.-D.); martiguillen18@gmail.com (J.M.M.-G.); sesperanza.martinez@um.es (S.E.M.-L.)

* Correspondence: rmrivero@cebas.csic.es; Tel.: +34-968396200 (ext. 6379)

\begin{abstract}
Metal toxicity in soils, along with water runoff, are increasing environmental problems that affect agriculture directly and, in turn, human health. In light of finding a suitable and urgent solution, research on plant treatments with specific compounds that can help mitigate these effects has increased, and thus the exogenous application of melatonin (MET) and its role in alleviating the negative effects of metal toxicity in plants, have become more important in the last few years. MET is an important plant-related response molecule involved in growth, development, and reproduction, and in the induction of different stress-related key factors in plants. It has been shown that MET plays a protective role against the toxic effects induced by different metals $(\mathrm{Pb}, \mathrm{Cd}, \mathrm{Cu}, \mathrm{Zn}, \mathrm{B}$, $\mathrm{Al}, \mathrm{V}, \mathrm{Ni}, \mathrm{La}, \mathrm{As}$, and $\mathrm{Cr}$ ) by regulating both the enzymatic and non-enzymatic antioxidant plant defense systems. In addition, MET interacts with many other signaling molecules, such as reactive oxygen species (ROS) and nitric oxide (NO) and participates in a wide variety of physiological reactions. Furthermore, MET treatment enhances osmoregulation and photosynthetic efficiency, and increases the concentration of other important antioxidants such as phenolic compounds, flavonoids, polyamines (PAs), and carotenoid compounds. Some recent studies have shown that MET appeared to be involved in the regulation of metal transport in plants, and lastly, various studies have confirmed that MET significantly upregulated stress tolerance-related genes. Despite all the knowledge acquired over the years, there is still more to know about how MET is involved in the metal toxicity tolerance of plants.
\end{abstract}

Keywords: metal toxicity; phytomelatonin; heavy metals; ROS; NO

\section{Introduction}

Environmental degeneration, which is mainly caused by rapid industrial expansion (transport, mining and energy industries, and intensive agriculture) has become a major threat to living beings. Heavy metals are increasingly polluting the water and soil of industrialized areas [1], and although plants need trace amounts of metals, such as iron $(\mathrm{Fe})$, copper $(\mathrm{Cu})$, and zinc $(\mathrm{Zn})$ to live, large amounts of them can induce severe stress on the plant, which directly affects plant productivity and, in turn, human health. The ratio of metal removal from soil by plants changes widely and is related to plant species, plant growth rate, and the concentration of heavy metals in the irrigation water or soil [2,3]. Currently, the most recent research interests are on finding plants known as heavy metal-hyperaccumulator plants, i.e., plants which have an extreme ability to accumulate one or more heavy metals [4-6], to provide an immediate solution for the recovery of contaminated soils.

In recent years, the exogenous application of melatonin (MET) has been shown as a possible solution to the cultivation of plants in contaminated soils and waters. MET is an antioxidant derivative of tryptophan that is mainly synthesized in mitochondria, 
chloroplasts, and to a lesser extent, in the cytosol $[7,8]$ and its content in plants differs depending on cultivars, species, growth and developmental periods, tissue types, and even in repetitions from a single experiment $[9,10]$. Especially in plants, MET is maintained at a relatively constant level under normal conditions, just as with reactive oxygen species (ROS), and it is therefore believed that MET may mainly act as a regulator of ROS levels. Nevertheless, MET and ROS synthesis and accumulation can be greatly and rapidly activated and upregulated in response to stress conditions [11,12]. Several studies have reported that MET could be considered a growth regulator, as it plays a role in specific physiological processes in plants [13-15]. In addition, some results have demonstrated that MET could be useful in phytoremediation processes [2]. Previous studies have shown that an exogenous treatment with MET improved plant tolerance to abiotic stress such as drought, heat, and cold in plants [16]. However, the most important function that was recently described for MET in living organisms was related to its role in non-receptormediated enzymatic activities, such as those related to ROS and reactive nitrogen species (RNS) scavenging, which increased and improved the cell's antioxidant capacity [9]. MET regulates the activity of different antioxidant enzymes and stress tolerance-related genes, and it is involved in the regulation of the downstream signaling transduction pathways in plants exposed to abiotic or biotic stress $[17,18]$. Also, MET improves the tolerance capacity of different plants cost-effectively and feasibly against environmental contamination, as it is considered an environmentally-friendly molecule. In this context, there is no evidence of serious MET toxicity in any plant, animal, or humans [19], although it has been shown that under special circumstances, high levels of MET may induce some growth inhibition [20].

Consequently, in the last few years, the study of exogenous MET application to plants to counteract metal toxicity, has increased. The first report in this area was published by Tan et al. [21], which correlated MET and N1-acetyl-N2-formyl-5-methoxykynuramine (AMFK, a melatonin derivative) contents with the tolerance capacity of water hyacinth plants against toxic pollutants [21]. The same research group demonstrated that the tolerance capacity of pea (Pisum sativum) plants significantly improved after supplementation with MET under $\mathrm{Cu}$ stress [19]. In general, it is believed that exogenous/endogenous MET improves metal toxicity tolerance capacities of plants by restricting metal mobility in the rhizosphere and aerial parts, along with boosting the activities of other key stress-related processes, such as vacuolar transporters, phytochelatins, and glutathione (GSH). These molecules are known to be further involved in the sequestration and detoxification of metals in plants, allowing for greater plant growth [22]. As a consequence, these results may offer an alternate use of MET in plants, as well as the improvement of human food safety.

MET functions have been comprehensively and deeply searched for in different plants under metal toxicity conditions. In this review, we summarize the most recent research conducted on metal toxicity in plants, and how MET treatments may improve metal stress tolerance in plants.

\section{Role of MET in Plants Subjected to Metal Toxicity}

The conditions under which plants usually grow are constantly changing, and plants are often subjected to various stress conditions. Therefore, improving plant stress resistance is not only critical for ensuring agronomic productivity, but also for environmental sustainability, as it has been demonstrated that crops with poor stress resistance consume more water and fertilizers [23]. Metal contamination is an important environmental problem, especially in areas with high anthropogenic pressure. Heavy metal accumulation directly influences crop growth due to phytotoxicity, agriculture due to the adverse effects of these metals on food safety and marketability, and the environmental health of soil organisms. As plants are an essential part of the ecosystem, and as they have a direct influence on the geological and biological redistribution of heavy metals that pollute the soil, water and air [24], knowledge on the effects of metal toxicity in plants and their response in such environments, is crucial for the development of improved agricultural traits and food production under these circumstances. 


\section{Effects of Metal Toxicity in Plants}

In general, high levels of metals $(\mathrm{Pb}, \mathrm{Cd}, \mathrm{Cu}, \mathrm{Zn}, \mathrm{B}, \mathrm{Al}, \mathrm{V}, \mathrm{Ni}, \mathrm{La}, \mathrm{As}$, and $\mathrm{Cr}$ ) produce stunted growth and abnormal morphology, perturbations in water relations, ion metabolism, and mineral uptake, a decrease in photosynthetic rate, stomatal conductance, chlorophyll a and $\mathrm{b}$ biosynthesis, and an increase in chlorophyll degradation. These toxicities also induce a common oxidative burst in plants which causes an imbalance in the production and scavenging of ROS, which reduces photosynthesis and induces stomatal closure, alters the activities of many enzymes and lastly, produces cell damage and death All of these effects have been shown to appear at high concentrations of $\mathrm{Pb}$ [25], $\mathrm{Cd}$ [26], $\mathrm{Cu}[27,28], \mathrm{Zn}$ [29], B [30,31], $\mathrm{Al}$ [32-34], V [35], Ni [36-38], As [39-41], and Cr [42] in the growth media of the plants.

More specifically, it has been shown that a high $\mathrm{Cu}$ concentration resulted in the deficiency of other micronutrients, which adversely affected the yield of wheat plants [28]. Zinc (Zn) toxicity is related to Fe-deficiency-induced chlorosis through reductions in chlorophyll synthesis and chloroplast degradation, and interference with $\mathrm{P}, \mathrm{Mg}$ and $\mathrm{Mn}$ uptake [29]. Vanadium $(\mathrm{V})$ is a chemical analogue of phosphorus $(\mathrm{P})$, and for this reason, it alters the $\mathrm{P}$ absorption capacity of plants [35]. An elevated nickel (Ni) level causes phytotoxicity, which influences nitrogen metabolism, ultimately expediting necrosis and senescence in plants $[36,38]$. In the same manner, chromium (Cr) toxicity has been associated to changes in the process of germination [42]. Therefore, the imbalance caused by heavy metals on the absorption and assimilation of other important nutrients directly affects plant growth and yield, and it is a serious problem for current agriculture. This heavy metal problem is increasing due to and along with industrialization and air/water pollution, so knowledge on which signaling mechanisms are affected by these heavy metal toxicities is essential to cope with this emerging problem.

\section{Roles of MET in Metal Toxicity Tolerance}

In general, the mechanisms that involve MET in the tolerance to metal toxicity are similar (Figure 1), although some MET-induced mechanisms are specific to a certain type of contaminant and plant species, which will be specifically described below. Thus, MET application improves photosynthesis efficiency, regulates metal transport and plant vegetative growth processes, decreases ROS and RNS levels and oxidative damage, and upregulates stress tolerance-related genes [43].
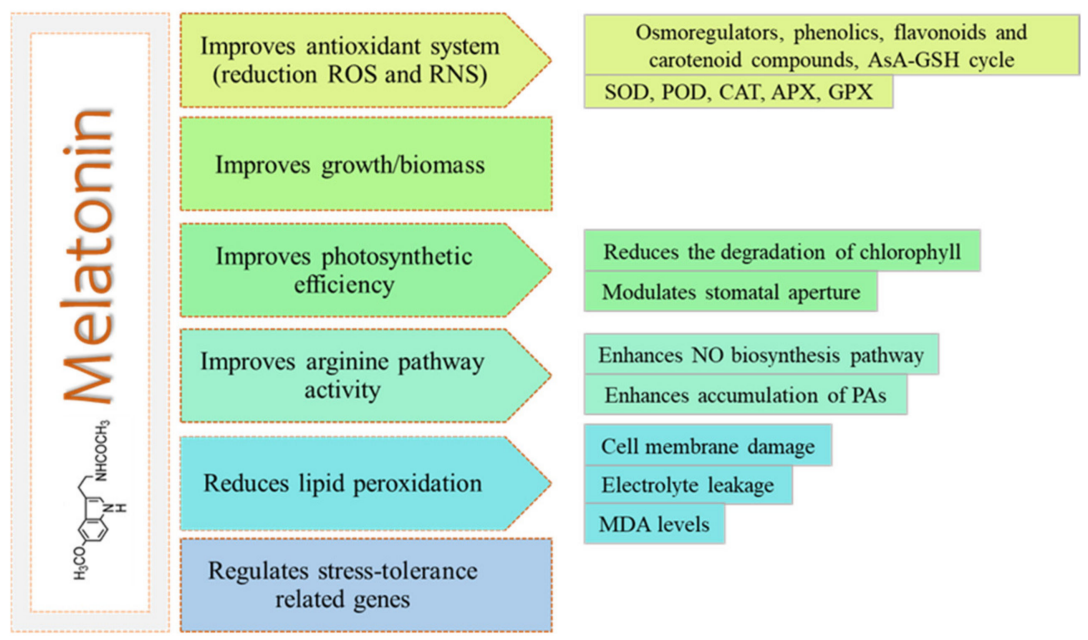

Figure 1. Common MET functions in metal toxicity tolerance. Reactive oxygen species (ROS), reactive nitrogen species (RNS), ascorbic acid (AsA), glutathione (GSH), catalase (CAT), superoxide dismutase (SOD), peroxidase (POD), ascorbate peroxide (APX), and glutathione reductase (GR), nitric oxide (NO), polyamines (PAs), malondialdehyde (MDA). 


\subsection{Regulation of Photosynthesis by the Application of Exogenous MET}

Perhaps one of the most significant functions of MET in plants is the role it plays on increasing photosynthetic efficiency, as MET helps to improve the integrity of the photosynthetic pigments, such as chlorophyll, and increases the rate of photosynthetic electron transport chain (PET), and D1 protein synthesis. Thus, it has been shown that MET application enhanced photosynthetic efficiency under $\mathrm{Pb}, \mathrm{C}, \mathrm{Cu}, \mathrm{Zn}, \mathrm{Al}, \mathrm{Ni}$, or $\mathrm{Cr}$ toxicity (Table 1). In these studies, all the authors concluded that MET helped to improve plant growth under these metal toxicities due to an improvement in photosynthetic efficiency.

Table 1. Selected studies on the roles played by melatonin on the photosynthesis efficiency response of plants to metal toxicity.

\begin{tabular}{ccc}
\hline Metal Toxicity & Plant Species & References \\
\hline \multirow{2}{*}{$\mathrm{Pb}$} & bermudagrass (Cynodon dactylon) & {$[44]$} \\
& Eruca vesicaria & {$[45]$} \\
\hline & alfalfa (Medicago sativa) & {$[46]$} \\
& tomato (Solanum lycopersicum) & {$[47-49]$} \\
& wheat (Triticum aestivum) & {$[50,51]$} \\
& Cyphomandra betacea & {$[52]$} \\
& Malachium aquaticum & {$[53]$} \\
& Galinsoga parviflora & {$[53]$} \\
$\mathrm{Cd}$ & Perilla frutescens & {$[54]$} \\
& rice (Oryza sativa) & {$[55,56]$} \\
& Ulva (green macroalga) & {$[57,58]$} \\
& mallow (Malva parviflora) & {$[59]$} \\
& Spinacia oleracea & {$[60]$} \\
& Chinese cabbage (Brassica campestris spp. chinensis) & {$[61]$} \\
& rapeseed (Brassica napus) & {$[62]$} \\
$\mathrm{Cu}$ & cucumber (Cucumis sativus) & {$[63]$} \\
$\mathrm{Zn}$ & strawberries (Fragaria $\times$ ananassa) & {$[64]$} \\
\hline $\mathrm{Al}$ & cucumber (Cucumis sativus) & {$[65]$} \\
\hline $\mathrm{V}$ & wheat (Triticum aestivum) & {$[66]$} \\
\hline $\mathrm{Ni}$ & rapeseed (Brassica napus) & {$[62]$} \\
\hline $\mathrm{Cr}$ & watermelon (Citrullus lanatus) & {$[67]$} \\
\hline & tomato (S. lycopersicum) & {$[68]$} \\
\hline & wheat (Triticum aestivum) & {$[69]$} \\
& canola (Brassica napus) & {$[70,71]$} \\
\hline
\end{tabular}

\subsection{MET Crosstalk with Other Plants Hormones}

Several researchers have defined MET as a growth regulator or a phytohormone, as it can regulate plant vegetative growth processes such as rooting, flowering, leaf aging, photosynthetic yield, biomass yield, or the formation and maturation of seeds and fruits [13-15]. Thus, the phytohormone MET can crosstalk with other plant hormones (abscisic acid, gibberellin A14, zeatin, 24-epibrassinolide, and jasmonic acid (JA)) to regulate these physiological processes [72]. The combined transcriptomic and metabolomic analysis described by Hu et al. [73] revealed that MET could promote melon (Cucumis melo) root development by regulating linoleic acid metabolism. MET decreased the level of linoleic acid and the expression of four lipoxygenase (LOX)-related genes, thus decreasing the level of JA. Therefore, MET decreased ROS damage induced by $\mathrm{Cu}$ stress in melon plants by reducing LOX-related gene expression and JA levels, thus regulating the expression of other redox genes and increasing antioxidant enzyme activities that detoxified cellular ROS [73]. 


\subsection{Regulation of Metal Transport by MET}

In several studies, MET has been shown to be involved in the regulation of metal transport in plants $[59,62,67,74-76]$. Namdjoyan et al. elucidated that MET application in safflower (Carthamus tinctorius) seedlings reduced $\mathrm{Pb}$ uptake and decreased $\mathrm{Pb}$ transfer from the root to the aerial parts of the plant [74] (Figure 2). Under the same stress, David et al. also demonstrated that the exogenous application of MET resulted in a thickened root cuticle and epidermis, which helped with the immobilization and localization of $\mathrm{Pb}$ to the root, and the decrease in the translocation of $\mathrm{Pb}$ to the leaves of Amaranthus cruentus [75] (Figure 2). In rapeseed (Brassica napus) seedlings, the analysis of $\mathrm{Cd}$ and $\mathrm{Al}$ in different subcellular compartments showed that MET restricted the mobilization of $\mathrm{Al}$ and $\mathrm{Cd}$ into vacuoles and the cell wall, and thus substantially decreased $\mathrm{Al}$ and $\mathrm{Cd}$ toxicity [62]. Similarly, in mallow (Malva parviflora) plants under Cd stress, low concentrations of MET led to a decrease in Cd translocation to the shoots [59]. In this way, Nawaz et al. (2018) showed that MET pretreatment of watermelon (Citrullus lanatus) seedlings increased the ability of the plants to accumulate $\mathrm{V}$ in the root tissues, thus reducing $\mathrm{V}$ transport from the root to stem and leaves [67] (Figure 2). However, in a Nazarian and Ghanati study [76], MET treatment of rice (Oryza sativa) plants under As stress was associated to As transport from roots to shoots, and therefore, a higher accumulation of As in shoots and suppression of the antioxidant system was observed. In another study, the effects of MET on the aquaporins (AQP) water channels were responsible for arsenic uptake and transport, which caused an intense increase in As concentrations in the aerial parts of rice plants. Both in the root and the aerial part, As adversely affected photosynthesis, growth, total sugar and protein production, and increased $\mathrm{H}_{2} \mathrm{O}_{2}$ content [76]. One of the essential characteristics of plants used in phytoremediation techniques is their ability to accumulate heavy metals into harvestable plant parts such as stems and leaves [74], with the aim of cleaning soils and/or waters of these metals. However, in most of the cases, MET improved the immobilization and the localization of metals to the root and decreased the translocation of metals to the leaves, which may help to not only clean soils and/waters from heavy metals, but also to commercialize the aerial parts of these plants for a safe human consumption, as they are clean of metals. In this sense, it is important to delve into the knowledge on the role of MET for the phytoremediation of contaminated soils and waters with edible plants/fruits.

Some more specific studies on metal stress tolerance in plants induced by MET have demonstrated that MET interacted with selenium (Se), $\mathrm{Ca}^{2+}$ or GSH to enhance metal toxicity tolerance. Li et al. [77] indicated that Se and MET supplements significantly increased $\mathrm{Cd}$ tolerance in tomato plants (Solanum lycopersicum) by optimizing plant growth parameters. Although exogenous selenocysteine could ameliorate Cd phytotoxicity, a basal level of endogenous MET was required for Se-conferred Cd tolerance, which may enhance the detoxification of $\mathrm{Cd}$ [77]. On the other hand, Goodarzi et al. [78] showed that the application of MET, GSH, and in particular, the combination of these two signaling molecules, could significantly reduce the dangerous effects of $\mathrm{Zn}$-induced toxicity in safflower (Carthamus tinctorius) by reducing $\mathrm{Zn}$ accumulation in the shoots of safflower seedlings, and stimulating various antioxidant defense systems [78]. In addition, Siddiqui et al. [79] found that a combination of MET and $\mathrm{Ca}^{2+}$ was more efficient than their separate use to increase the tolerance of Vicia faba plants under metalloid As toxicity. Under As toxicity conditions, the application of MET and $\mathrm{Ca}^{2+}$ synergistically suppressed the apoptosis of stomata guard cells, DNA damage, and formation of ROS. Furthermore, it improved photosynthesis efficiency under these conditions. In addition, the expressions of ATP synthase, $\mathrm{Ca}^{2+}$-ATPase, $\mathrm{Ca}^{2+}$ - DPKase, Hsp17.6 and Hsp40 were found at their maximum in plants treated with $\mathrm{MET}+\mathrm{Ca}^{2+}$, resulting in a higher tolerance of plants to As stress. Ultimately, $\mathrm{MET}+\mathrm{Ca}^{2+}$ treated plants conferred As toxicity tolerance shown as increased total soluble carbohydrates, cysteine, and proline (Pro) accumulation with increased Pro synthesizing enzyme ( $\Delta 1$-pyrroline-5-carboxylate synthetase (P5CS), and decreased Pro degrading enzyme (Pro dehydrogenase) [79]. On the other hand, Zhang et al. [80] showed that an arbuscular mycorrhizal (AM) inoculation and MET application had a synergistic 
effect on host Medicago truncatula plant growth and $\mathrm{Pb}$ stress tolerance. In this synergy, $\mathrm{AM}$ inoculation may stimulate the accumulation of MET through the upregulation of ASMT (acetylserotonin methyltransferase, the enzyme that participates in the last step of the MET synthesis pathway) in roots. Moreover, the application of MET could improve mycorrhizal plant growth and $\mathrm{Pb}$ stress tolerance by improving $\mathrm{AM}$ symbiosis and stimulating an antioxidant response [80].

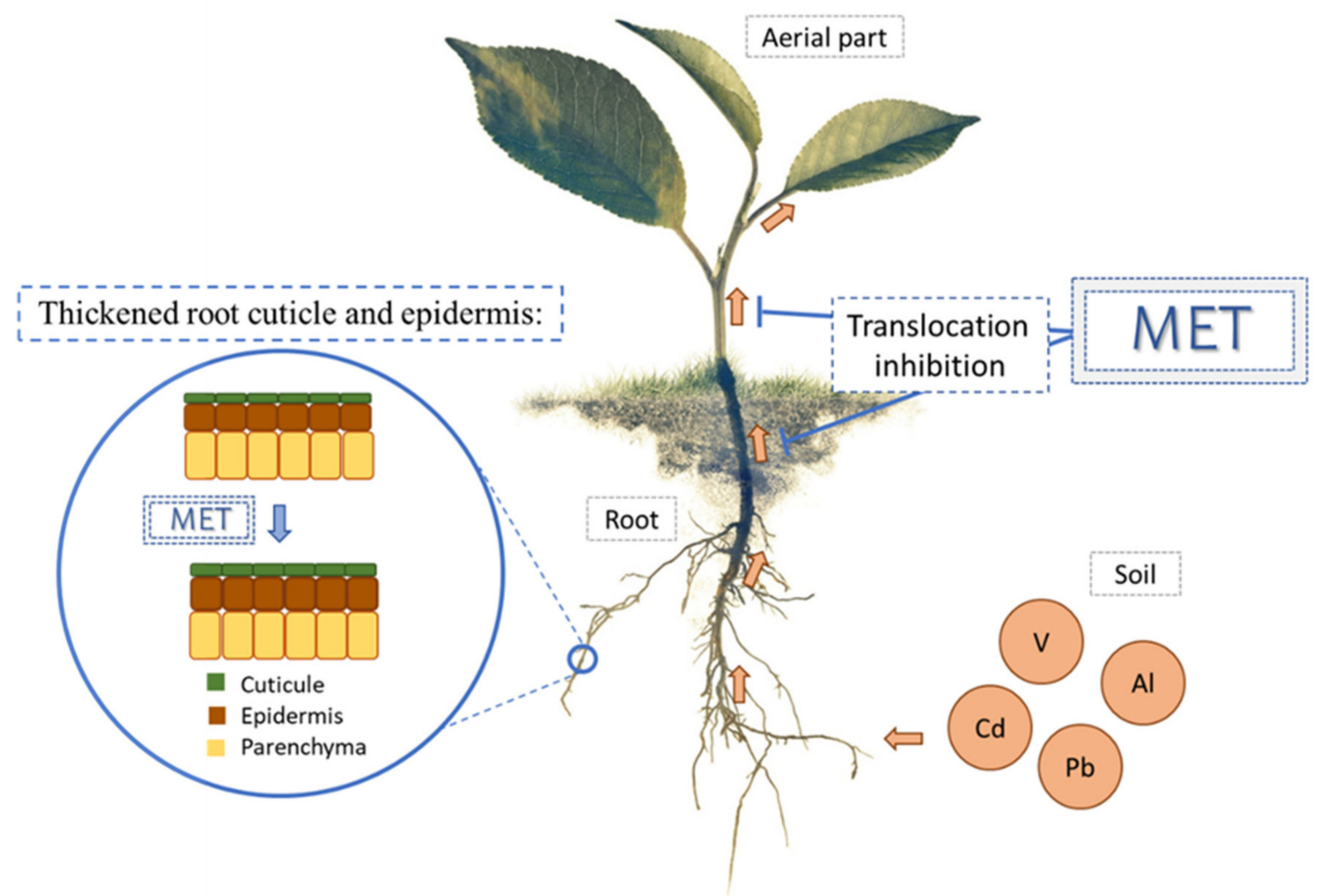

Figure 2. Regulation of metal transport by MET. Treatment of MET decreased $\mathrm{Pb}, \mathrm{Cd}, \mathrm{V}$ and $\mathrm{Al}$ transfer from root to aerial parts of the plant. In addition, exogenous MET was related to the thickened root cuticle and epidermis.

\section{ROS and NO-Related MET Induced Stress Response in Plants}

As described previously, plant responses to metal stress are complex. To reduce injury due to stress, plants have developed different pathways. The first stress response is the concomitant increase in ROS and RNS within the cells. ROS and RNS play an essential role as signaling molecules in the regulation of numerous biological processes such as growth, development, and abiotic and/or biotic stress responses in plants [81]. The temporal and spatial coordination between ROS and other signaling molecules is very well known as a primary mechanism of plant-related stress responses. Different studies have identified multiple core sets of genes and stress condition-dependent changes [81]. The levels of ROS and RNS are especially important in plants, as they are related to lipid peroxidation, electron leakage (EL), and resulting membrane damage, as well as damage to proteins and nucleic acids [82].

Transition metals, such as $\mathrm{Cu}$, catalyze the formation of hydroxyl radicals from Fenton and Haber-Weiss reactions [83]. However, $\mathrm{Cd}$ and $\mathrm{Hg}$ do not seem to be able to intervene in these types of reactions, and although they are known to be potent inducers of oxidative stress $[84,85]$, how this stress is induced is still unknown. Under heavy metal stress, nicotinamide adenine dinucleotide phosphate (NADPH)- oxidase is perhaps the main source of $\mathrm{H}_{2} \mathrm{O}_{2}$ and ROS that mainly accumulate in the apoplast after $\mathrm{O}_{2}{ }^{\bullet-}$ generation [86,87]. In pea plants, exposure to $\mathrm{Cd}$ has been shown to generate a response that was characterized by an overproduction of ROS and a decrease in nitric oxide (NO) [86]. On the other hand, it has been shown that intracellular ROS production constantly increased in alfalfa seedlings exposed to $\mathrm{Cd}$, with a lower increase in extracellular $\mathrm{H}_{2} \mathrm{O}_{2}$. Nevertheless, a small $\mathrm{Hg}$ 
treatment in epidermal cells of alfalfa roots caused an oxidative burst, as observed by a constant increase in extracellular $\mathrm{H}_{2} \mathrm{O}_{2}$ in roots, while intracellular ROS accumulated only temporarily [88]. Thus, $\mathrm{Hg}$ and $\mathrm{Cd}$ trigger different toxicity mechanisms [88]. In general, metals such as $\mathrm{Cd}, \mathrm{Cu}, \mathrm{Fe}, \mathrm{Zn}, \mathrm{Hg}, \mathrm{Mn}$, and $\mathrm{Al}$ have been shown to induce ROS production as a generalized response. Afterwards, ROS scavenging systems, including catalase (CAT), superoxide dismutase (SOD), peroxidase (POD), ascorbate peroxide (APX), and glutathione reductase (GR) often work together in the protection against excess ROS toxicity in plants [89].

Recently, it was shown that one of the molecules that was able to regulate the cellular concentration of ROS, was MET [17]. In this sense, it has been proposed that endogenous MET concentration is able to control ROS levels in two different ways: through its direct chemical interaction with ROS (i.e., ROS scavenger) which results in their detoxification [90-92]; or by the MET-mediated induction of the main antioxidant enzymes [93], such as SODs, APXs, and CATs, among others. As well, MET increases the accumulation of some representative non-enzymatic antioxidant compounds, such as GSH and ascorbic acid (AsA) [94-101], phenolic compounds [102], flavonoids via the nitric oxidedependent (NO-dependent) pathway [103], and carotenoids [72,104], which help in ROS detoxification. Exogenous MET interacts with its main cellular receptor (CAND2/PMTR1), which could be MET-induced, leading to the activation of responses against stressors [105]. In addition, Arnao and Hernadez-Ruiz [92] showed that ROS can upregulate the MET biosynthesis genes and consequently, enhance the plant's endogenous levels of MET, thereby directly helping in the antioxidant plant response [92].

\subsection{ROS-Related MET Induced Stress Response in Plants}

Aside from its role as an antioxidant molecule, endogenous and exogenous MET are associated with a decrease in ROS levels and an increase in redox homeostasis due to the enhanced scavenging activity or the expression of some antioxidant enzymes, such as CAT, SOD, POD, GPX and, APX under most of the metal toxicity studies with metals including $\mathrm{Pb}, \mathrm{Cd}, \mathrm{Cu}, \mathrm{Zn}, \mathrm{B}, \mathrm{Al}, \mathrm{V}, \mathrm{Ni}, \mathrm{As}$, or $\mathrm{Cr}$ (Table 2). The increased activity of antioxidant enzymes decreased EL, lipid peroxidation, malondialdehyde (MDA) content, and ROS content in the plants exposed to metal stress $[59,64]$, which are usually increased and related to cell damage induced by stress (Figure 3).

Table 2. Selected studies on the roles played by MET treatment related with a decrease in ROS levels and an increase in redox homeostasis, due to the enhanced scavenging activity or the expression of some antioxidant enzymes, enhanced non-enzymatic antioxidant molecules, such as GSH and AsA (AsA-GSH cycle) and cell osmoegulation.

\begin{tabular}{|c|c|c|c|}
\hline ROS Regulation & Metal Toxicity & Plant Species & References \\
\hline & $\mathrm{Pb}$ & $\begin{array}{c}\text { bermudagrass (Cynodon dactylon) } \\
\text { maize }(Z . \text { mays }) \\
\text { Ulva (green macroalga) }\end{array}$ & $\begin{array}{c}{[44]} \\
{[106]} \\
{[58]}\end{array}$ \\
\hline Antioxidant enzymes & $\mathrm{Cd}$ & $\begin{array}{c}\text { mallow (Malva parviflora, Malvaceae) } \\
\text { Spinacia oleracea } \\
\text { strawberries (Fragaria } \times \text { ananassa) } \\
\text { alfalfa (Medicago sativa) } \\
\text { tomato (Solanum lycopersicum) } \\
\text { wheat (Triticum aestivum) } \\
\text { Cyphomandra betacea } \\
\text { Malachium aquaticum } \\
\text { Galinsoga parviflora } \\
\text { Perilla frutescens } \\
\text { rice (Oryza sativa) } \\
\text { Ulva (green macroalga) } \\
\text { rapeseed (Brassica napus) } \\
\text { cucumber (Cucumis sativus) }\end{array}$ & $\begin{array}{c}{[59]} \\
{[60]} \\
{[64]} \\
{[46]} \\
{[47-49]} \\
{[50,51]} \\
{[52]} \\
{[53]} \\
{[53]} \\
{[54]} \\
{[55,56]} \\
{[57,58]} \\
{[62]} \\
{[63]}\end{array}$ \\
\hline
\end{tabular}


Table 2. Cont

\begin{tabular}{|c|c|c|c|}
\hline ROS Regulation & Metal Toxicity & Plant Species & References \\
\hline & $\mathrm{Cu}$ & $\begin{array}{l}\text { cucumber (Cucumis sativus) } \\
\text { melon (Cucumis melo) }\end{array}$ & $\begin{array}{l}{[65]} \\
{[73]}\end{array}$ \\
\hline & $\mathrm{Zn}$ & $\begin{array}{c}\text { Ulva (green macroalga) } \\
\text { wheat (Triticum aestivum) } \\
\text { safflower (Carthamus tinctorius) }\end{array}$ & $\begin{array}{l}{[58]} \\
{[60]} \\
{[78]}\end{array}$ \\
\hline & $\mathrm{Al}$ & $\begin{array}{l}\text { soybean (Glycine max) } \\
\text { Wheat (Triticum aestivum) } \\
\text { rapeseed (Brassica napus) }\end{array}$ & $\begin{array}{l}{[107]} \\
{[108]} \\
{[62]}\end{array}$ \\
\hline & $\mathrm{V}$ & watermelon (Citrullus lanatus) & [67] \\
\hline & $\mathrm{Ni}$ & tomato (S. lycopersicum) & [68] \\
\hline & $\mathrm{Cr}$ & $\begin{array}{l}\text { wheat (Triticum aestivum) } \\
\text { canola (Brassica napus) }\end{array}$ & $\begin{array}{l}{[69]} \\
{[71]}\end{array}$ \\
\hline & B & wheat (Triticum aestivum) & [30] \\
\hline & As & $\begin{array}{c}\text { rosemary (Rosmarinus officinalis) } \\
\text { rice (Oryza sativa) }\end{array}$ & $\begin{array}{c}{[109]} \\
{[41,76]}\end{array}$ \\
\hline \multirow{7}{*}{ AsA-GSH cycle } & $\mathrm{Pb}$ & $\begin{array}{c}\text { bermudagrass (Cynodon dactylon) } \\
\text { maize (Z. mays) } \\
\text { Ulva (green macroalga) }\end{array}$ & $\begin{array}{c}{[44]} \\
{[106]} \\
{[58]}\end{array}$ \\
\hline & $\mathrm{Cd}$ & $\begin{array}{c}\text { mallow (Malva parviflora, Malvaceae) } \\
\text { cucumber (Cucumis sativus) } \\
\text { strawberries (Fragaria } \times \text { ananassa) }\end{array}$ & $\begin{array}{l}{[59]} \\
{[110]} \\
{[64]}\end{array}$ \\
\hline & $\mathrm{Cu}$ & cucumber (Cucumis sativus) & {$[65]$} \\
\hline & $\mathrm{Ni}$ & tomato (S. lycopersicum) & [68] \\
\hline & $\mathrm{Cr}$ & $\begin{array}{c}\text { wheat (Triticum aestivum) } \\
\text { canola (Brassica napus) }\end{array}$ & $\begin{array}{l}{[69]} \\
{[71]}\end{array}$ \\
\hline & B & wheat (Triticum aestioum) & [30] \\
\hline & As & $\begin{array}{c}\text { rosemary (Rosmarinus officinalis L.) } \\
\text { rice (Oryza sativa) }\end{array}$ & $\begin{array}{c}{[109]} \\
{[41,76]}\end{array}$ \\
\hline \multirow{5}{*}{$\begin{array}{l}\text { Osmoregulation by carbohydrates } \\
\text { (trehalose) and amino acids } \\
\text { (proline) regulation }\end{array}$} & $\mathrm{Cd}$ & $\begin{array}{c}\text { Catharanthus roseus } \\
\text { Brassica napus } \\
\text { mallow (Malva parviflora) }\end{array}$ & $\begin{array}{l}{[111,112]} \\
{[62]} \\
{[59]}\end{array}$ \\
\hline & $\mathrm{Cu}$ & melon (Cucumis melo) & [73] \\
\hline & $\mathrm{Al}$ & Brassica napus & [62] \\
\hline & B & pepper (Capsicum annuum) & [113] \\
\hline & As & $\begin{array}{c}\text { Vicia faba } \\
\text { rosemary (Rosmarinus officinalis) }\end{array}$ & $\begin{array}{c}{[79]} \\
{[109]}\end{array}$ \\
\hline
\end{tabular}

The increased activity of antioxidant enzymes decreased EL, lipid peroxidation, malondialdehyde (MDA) content, and ROS content in the plants exposed to metal stress [59,64]. Moreover, MET supplementation has been shown to improve representative non-enzymatic antioxidant molecules, such as GSH and AsA (AsA-GSH cycle) under stress due to $\mathrm{Pb}, \mathrm{Cd}$, $\mathrm{Cu}, \mathrm{B}, \mathrm{Ni}$, As, or $\mathrm{Cr}$ (Table 2) (Figure 3). Furthermore, a disturbance in the redox potential of tissues under metal toxicity results in the accumulation of various osmolytes and the activation of antioxidant compounds. Osmotic potential is regulated by osmolytes within plant tissues, e.g., in Silene vulgaris, Cd was shown to inhibit water transport and originated higher proline levels, thus avoiding Cd-induced lipid peroxidation [114]. The accumulation of proline in a plant is considered as a physiological adaptation under environmental stresses [115]. At the cellular level, variations in the concentrations of osmolyte can lead 
to a series of modifications in the active constituents (e.g., pectin, lipid, and protein) of the cell wall and the cytomembrane [116,117]. Additionally, the complexation of major osmolytes with intracellular metal ions can convert the chemical forms of the metal in cells, which are closely associated with the translocation and subcellular distribution of the metal [118-121]. In this sense, exogenous MET was shown to increase the concentration of important molecules associated with cell osmoregulation, such as some carbohydrates (trehalose) and amino acids (Pro), which are commonly accumulated to protect plants against metal stress such as $\mathrm{Cd}, \mathrm{Cu}, \mathrm{B}, \mathrm{Al}$, or As toxicity (Table 2). It has also been described that in mallow (Malva parviflora) plants under Cd toxicity, a MET treatment increased phenylalanine ammonia-lyase (PAL) activity, a key enzyme related to defense reactions and the main step in the phenylpropanoid synthesis pathway. These authors argued that an increase in shoot soluble carbohydrates could be related to an increased content of phenols in these plants under Cd toxicity [59]. This was also described for Vicia faba plants, where the exogenous application of MET induced the accumulation of total soluble carbohydrates, cysteine, and Pro, with the concomitant increase of the Pro-synthesis enzyme ( $\Delta 1$-pyrroline-5-carboxylate synthetase, P5CS), and a decrease in the Pro-degrading enzyme (Pro dehydrogenase-PDH) [79].

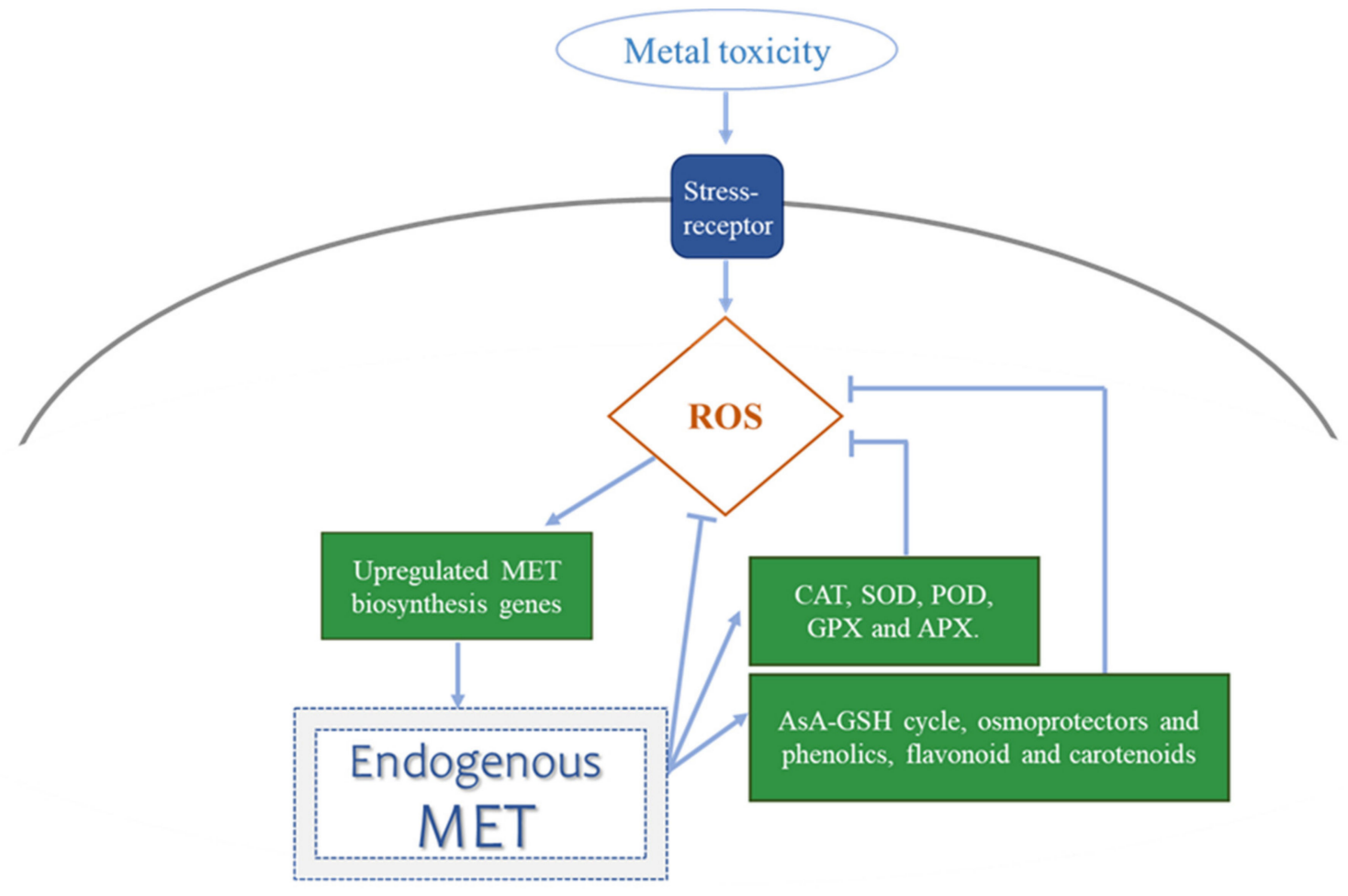

Figure 3. Interaction between melatonin (MET) and reactive oxygen species (ROS). ROS upregulate MET biosynthesis genes and enhance MET endogenous levels. MET can act as a ROS scavenger and control ROS levels through the melatoninmediated induction of redox enzymes, such as CAT, SOD, POD, GPX and APX, as well as non-enzymatic antioxidant compounds, such as GSH and AsA (AsA-GSH cycle), osmoprotectants, and phenolic, flavonoid and carotenoid compounds.

Other non-enzymatic antioxidant molecules which have been shown to increase their concentration after an exogenous application of MET are phenolic compounds, flavonoids, and carotenoid compounds via the NO-dependent pathway $[30,72,104,113,122]$. The application of MET in wheat (Triticum aestivum) under high levels of B significantly reversed the adverse effects of B toxicity and alleviated the cellular oxidative damage through enhanced ROS scavenging, by the induction of some important antioxidant enzymes, the increase in AsA and GSH content, and the content of phenolic compounds [30]. Also, in pepper plants (Capsicum annuum) grown under B toxicity, an exogenous application of MET reversed the 
toxic effect of B by moderating B accumulation and increasing carbohydrate, carotenoid, and flavonoid contents in leaves and fruits, with the concomitant increase in photosynthetic activity and plant growth [113]. Similar results and conclusions have been obtained in spinach plants (Spinacia oleracea) exposed to high B concentrations [122].

Furthermore, some studies have shown that MET addition to the growth media improved arginine pathway activity, and consequently, the concentration of endogenous polyamines (PAs) increased under several types of abiotic stress, including metal toxicity [98,123-125]. In this sense, in cucumber (Cucumis sativus) plants grown under $\mathrm{Cd}$ toxicity, the addition of 2-hydroxymelatonin (2-OHMET) enhanced photosynthetic rate, intercellular $\mathrm{CO}_{2}$ concentration, stomatal conductance, and the activity of PA-biosynthesis enzymes (putrescine, spermidine and spermine), while at the same time reducing PA oxidase activity. 2-OHMET also reduced $\mathrm{Cd}$ toxicity through the upregulation in the expression of SOD, CAT, and APX and improved antioxidant scavenger activity to reduce $\mathrm{H}_{2} \mathrm{O}_{2}$, EL, and MDA in these plants [63].

Finally, some researchers have confirmed that MET significantly upregulated stress tolerance-related genes. Kobylińska and Posmyk [126] observed that a MET treatment on $\mathrm{Pb}$-exposed Nicotiana tabacum line Bright Yellow 2 (BY-2) suspension cells increased the cells' viability, and this beneficial effect was correlated with a drastic decrease in $\mathrm{H}_{2} \mathrm{O}_{2}$ concentration and lipid peroxidation but also with a change in the expression of the BI-1 protein (an accepted regulator of plant cell death) [126]. Additionally, a recent investigation conducted by Wang et al. [127] revealed that the foliar application of MET in tobacco (Nicotiana tabacum) leaves enhanced $\mathrm{Cd}$ tolerance by improving antioxidant defense activities, promoting cell wall or vacuolar sequestration of $\mathrm{Cd}$ and changing the expression of $\mathrm{Cd}$ related genes (IRT1, Nramp1, HMA2, HMA4, and HMA3) [127]. In this way, Xu et al. firstly demonstrated that various candidate differentially-expressed genes encoding yellow stripe 1-like (YSL), heavy metal ATPases (HMA), and ATP-binding cassette (ABC) transporters were essential in the stress tolerance response, as they are involved in MET-mediated regulatory networks of $\mathrm{Cd}$ transportation and sequestration in radish (Raphanus sativus) roots. $\mathrm{Xu}$ et al. [128] also showed that the exogenous MET conferred Cd tolerance by the upregulation of the RsMT1 gene in radish plants [128]. As well, in MET-treated Chinese cabbage (Brassica campestris spp. chinensis) plants the concentration of $\mathrm{Cd}$ and the expression levels of related transport gene IRT1 were significantly reduced [61]. The transcriptome analysis by Cao et al. [65] demonstrated that MET broadly altered the expressions of various genes in cucumber (Cucumis sativus) under Cu stress. MET increased the levels of GSH and phytochelatin to chelate excess $\mathrm{Cu}$, and improved cell wall trapping, thus keeping more $\mathrm{Cu}$ in the cell wall and in the vacuole, thereby reducing its cellular toxicity. MET inhibited ROS production and enhanced antioxidant systems at the transcriptional level and enzymatic activities [65]. Furthermore, at the transcriptomic and metabolomic levels, Hu et al. [73] showed that there were 70 significant differentially expressed genes (DEGs) (28 upregulated, 42 downregulated) and 318 significantly differentially expressed metabolites (DEMs) (168 upregulated, 150 downregulated) between the MET and the no-MET treatments in melon plants under $\mathrm{Cu}$ stress. Thus, these authors demonstrated that MET could promote melon root development by regulating the metabolism of linoleic acid. MET decreased the level of linoleic acid and the expression of four lipoxygenase (LOX)-related genes, thus reducing the JA level. MET decreased ROS damage by decreasing LOX-related gene expression and JA accumulation, enhancing antioxidant enzyme activities, and modulating the expression of other redox genes. Moreover, MET increased GSH, which diminished excess $\mathrm{Cu}^{2+}$. MET also regulated the expression of genes related to cell wall formation mechanisms, and AP2/ERF, BBR/BPC, GRAS, and HD-ZIP transcription factor families. Then, these processes were related to MET-alleviated copper toxicity and promoted melon root development [73]. Very recently, Li et al. [129], showed that in tea (Camellia sinensis) plants, a MET treatment alleviated As phytotoxicity through the increase in anthocyanins due to the exogenous MET upregulating the expression of anthocyanin biosynthetic genes such as CsCHS and CsANS, as anthocyanins have a potential function in ROS detoxifi- 
cation and metaloid chelation. Interestingly, the analysis of As content suggesting that MET improved As tolerance was dependent on the basal levels of anthocyanins in tea plants [129].

\subsection{NO-Related MET-Induced Stress Response in Plants}

Nitric oxide (NO) is another key signaling molecule in plant physiology. The signaling role of NO in plants has also been reported to regulate plant growth under control and stress conditions [130]. Treatment with exogenous NO prevents damage from stress, promotes disease tolerance, improves the nutritional quality of fruits, and delays fruit ripening [131]. NO plays an important role in the regulation of the cellular redox balance in plant cells through post-translational modifications (PTMs) and/or through its binding to the prosthetic heme group of a few antioxidant enzymes. These PTMs include Snitrosylation, tyrosine nitration, and metal nitrosylation, with the first two being the most important at a physiological level [132]. Protein tyrosine nitration $\left(\mathrm{NO}_{2}\right.$-Tyr) consists of the addition of a nitro $\left(-\mathrm{NO}_{2}\right)$ group to one of the two equivalent ortho carbons of the aromatic ring of tyrosine residues [133]. S-nitrosylation is the covalent binding of NO to the thiol group of cysteines $[134,135]$. $\mathrm{NO}_{2}$-Tyr and S-nitrosylation can alter protein functions through a gain, no change, or loss of function, with the latter being the most common in plants $[132,136]$. Several studies have shown an interrelationship between S-nitrosylation and $\mathrm{NO}_{2}$-Tyr in the regulation of the activity of some antioxidant proteins, being an important mechanism for maintaining the antioxidant capacity of the AsA/GSH (ascorbic acid/glutathione) cycle under nitro-oxidative conditions [137,138]. Also, NO also regulates other important proteins related to other cellular processes. NO functions as a $\mathrm{Ca}^{2+}$-mobilizing messenger by promoting the rise in cytosolic $\mathrm{Ca}^{2+}$ concentrations. By increasing cytosolic $\mathrm{Ca}^{2+}$ concentration, $\mathrm{NO}$ regulates the activity of protein kinases and $\mathrm{Ca}^{2+}$-sensitive channels, which might be involved in the signaling cascade that causes the expression of defense-related genes (tolerance response to biotic and abiotic stresses), stomatal closure, or adventitious root formation, and germination. These processes involve cyclic adenosine diphosphate (cADP) ribose, cyclic guanosine monophosphate (cGMP), and protein kinases [139].

Recent studies have shown evidence of MET enhancing the NO biosynthesis pathway through the regulation of endogenous $\mathrm{NO}$ content, nitrate reductase (NR) and NO synthase-related activities (via the arginine pathway), and the expression of their related genes $[98,125,140]$. As well, it has also been demonstrated that NO can upregulate MET, through the direct regulation of this molecule of MET-related biosynthetic enzymes [94]. Also, NO regulates MET accumulation through the formation of N-Nitrosomelatonin (NOMET) [141]. In the presence of oxygen, MET can be efficiently converted to NOMET by NO nitrosylation under different $\mathrm{pH}$ conditions. Nevertheless, under the presence of serotonin and its derivatives, NOMET is an effective NO donor in cell cultures [142,143]. MET is transported in the form of a metabolic signal NOMET from the roots, across the hypocotyl, until reaching the cotyledon cells in less than $48 \mathrm{~h}$ after radicle emergence, leading to a reduction in both oxidative and nitrosative stress in sunflower seedlings under salt stress. That is, NO plays a role as a positive modulator of MET accumulation in seedling cotyledons in a long-distance signaling response [141]. More studies are needed to understand the interconnection between MET and NO. Nevertheless, a considerable number of studies have demonstrated that MET increases NO levels under abiotic stress [94,98,125,140,141,144-147] (Figure 4). 


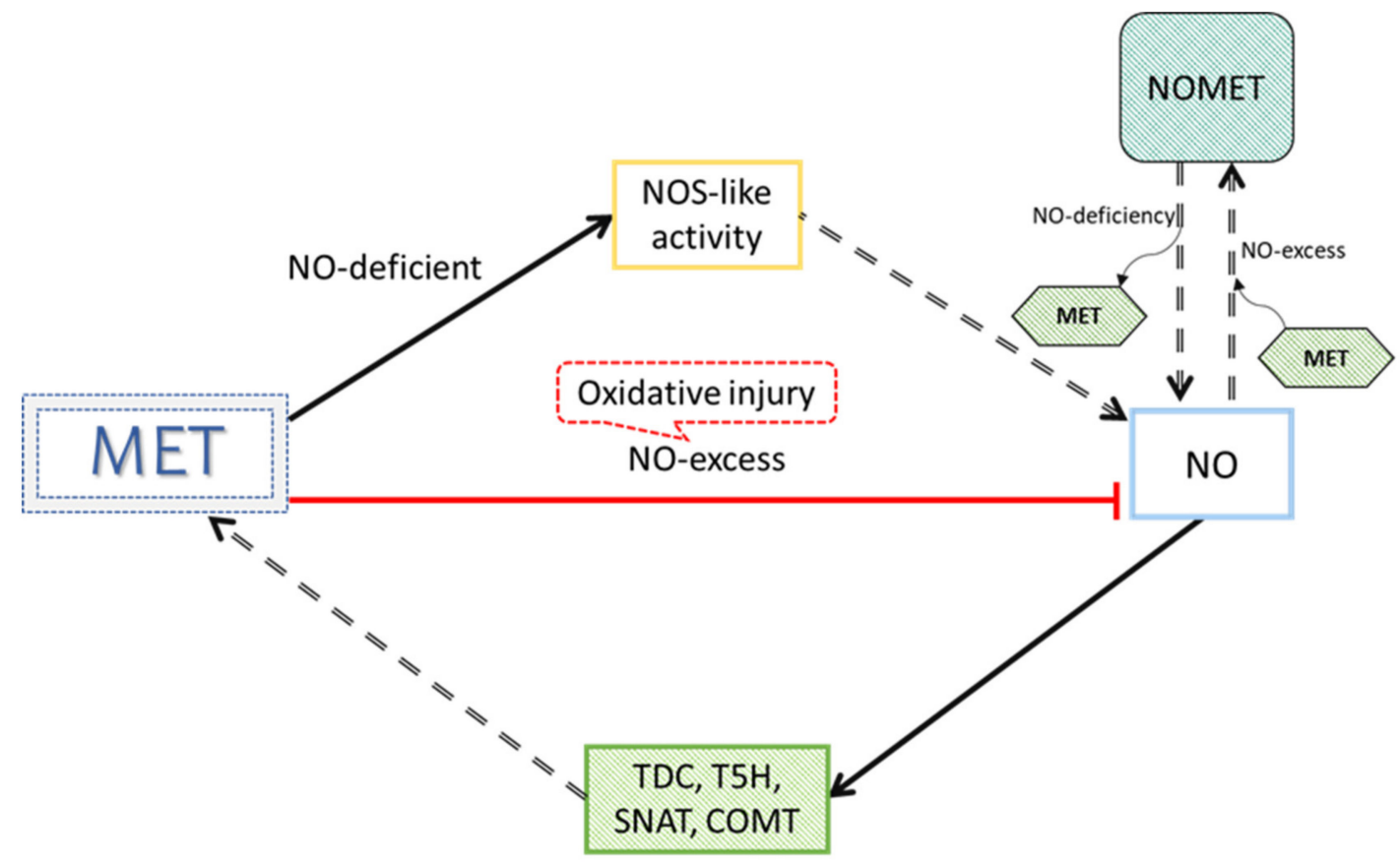

Figure 4. Interaction between melatonin (MET) and nitric oxide (NO). MET promotes the accumulation of NO by increasing the activity of NOS (nitric oxide synthase) by MET-mediated up-regulation of related genes. MET scavenges excess NO, as it produces oxidative injury (red arrow). In the presence of oxygen, MET can be easily converted to N-Nitrosomelatonin (NOMET) by NO nitrosation under different $\mathrm{pH}$ conditions, being NOMET an effective NO donor in cell cultures under the presence of serotonin and its derivatives. On the other hand, through a cyclic guanosine monophosphate (cGMP)-dependent pathway, NO induces the expression of TDC, T5H, SNAT and COMT genes that codify for the MET biosynthesis pathway enzymes to increase MET levels (these two process has not been described in plants grown under metal toxicity, although something similar was shown under other abiotic stresses). Abbreviations: Tryptophan decarboxylase (TDC), tryptamine5hydroxylase (T5H), serotonin N-acetyltransferase (SNAT), and caffeic acid O-methyltransferase (COMT). Modified figure from our previous article [16].

The MET and NO coordination enhances many metal toxicity-related tolerance in plants, such as Pb toxicity in maize [106], Cd toxicity in Catharanthus roseus [111,112,148], wheat (Triticum aestivum) [50] and Chinese cabbage (Brassica campestris spp. chinensis) [61], $\mathrm{Zn}$ toxicity in rice plants [149] and Al toxicity in Arabidopsis thaliana [150] plants. Nabaei and Amooaghaie [148] confirmed that co-treatment of MET and NO, improved Cd tolerance and phytoremediation efficiency in Catharanthus roseus plants. The pre-assumption of the additive effect of MET and NO or the hypothesis that these signal molecules have synergistic relationships for enhancing tolerance and accumulation of Cd in C. roseus plants [148] have also been shown. Studies in C. roseus showed that MET and sodium nitroprusside (SNP as a NO donor) significantly improved seedling growth by increasing the concentration of photosynthetic pigments, endogenous NO concentration in roots, Pro concentration, and the activities of antioxidant enzymes (SOD, POD, APX, and CAT). All of these were induced to lower $\mathrm{H}_{2} \mathrm{O}_{2}$ and lipid peroxidation levels in roots of $C$. roseus plants under $\mathrm{Cd}$ stress. On the other hand, it seemed that NO acted downstream of MET in modulating seed germination [112] and antioxidant responses in roots [111] of C. roseus plants under Cd toxicity. In MET-treated Chinese cabbage (Brassica campestris spp. chinensis plants, Wang et al. showed a significantly reduced concentration of $\mathrm{Cd}$ and expression levels of related transport genes IRT1 (regulators of Cd absorption). Under Cd toxicity, NO increases the expression of IRT1, thus further increasing the absorption of $\mathrm{Cd}$ and intensifying the stress of $\mathrm{Cd}$ in plants, while an exogenous treatment with MET under $\mathrm{Cd}$ toxicity inhibits the synthesis of NO, and therefore, MET reduces the Cd content in the plant and Cd toxicity as well [61]. Huang et al. revealed that MET application substantially increased dry biomass accumulation, root growth, mineral absorption, and antioxidant responses of rice under 
various levels of $\mathrm{ZnO}$ nanoparticle application. The $\mathrm{NO}$ induced in rice plant plays an important role in producing resistance against $\mathrm{ZnO}$ nanoparticle toxicity by regulating MET metabolism and antioxidant enzyme activities. Their comparative transcriptome analysis also identified key genes which were responsible for MET and NO-induced modulations in plant growth under $\mathrm{ZnO}$ nanoparticle toxicity [149]. Additionally, pharmacological and genetic evidence in Arabidopsis thaliana also suggested that exogenous and endogenous MET concentrations were involved in the alleviation of $\mathrm{Al}$ toxicity-induced root growth inhibition, through the interference of the NO signaling pathway [150]. Finally, Zhang et al. demonstrated that the expression of serotonin $\mathrm{N}$-acetyltransferase (SNAT), encoding a key enzyme involved in MET synthesis, was downregulated by $\mathrm{Al}$, which coincided with decreased MET accumulation in Arabidopsis thaliana. That is, SNAT-mediated MET synthesis played a critical role in $\mathrm{Al}$ toxicity resistance [150].

\section{Conclusions and Future Perspectives}

In plants melatonin (MET) is associated to numerous functions, among which we find the regulation of physiological processes such as flowering or rooting, and its involvement in tolerance to abiotic and biotic stress conditions. MET alleviates metal stress or metal toxicity directly through the scavenging of ROS and RNS, and indirectly through the enhancement of antioxidant activities and photosynthetic capacity, the regulation of plant growth regulators, the increase of osmotic metabolites, the regulation of metal transport, and the downregulation or upregulation of stress-related genes in plants. However, relatively few studies have been focused on the genes and core pathways that are specifically regulated by MET. In addition, several researchers have revealed that MET is involved in the signaling pathway that is directly mediated by NO, although their relationship is still confusing. More research works are needed to comprehend the relation between endogenous MET and NO, as most studies have only focused on exogenous MET. In this sense, no studies have been found that showed the implication of the relationship between MET and abscisic acid (ABA), or ethylene in plants, on the tolerance to metal toxicity. However, different studies have demonstrated that ABA-dependent pathways may have contributed to MET-induced cold and salinity tolerance [151,152] and that ethylene production was suppressed by MET through the downregulation of the ethylene biosynthesis-related genes under waterlogging stress in plants [124]. On the other hand, apart from the toxicity produced by the metals mentioned in this review, it has been observed that MET can also increase the tolerance in plants subjected to stress due to pollutants such as lanthanum [153], selenium [154], fluoride ions [155,156], and bisphenol A [BPA; 2,2-bis(4-hydroxybenzene)] [157], which will need further investigation due to the importance of these toxic molecules for human health. Therefore, the knowledge of the different signaling mechanisms that involve MET in heavy metal detoxification could lead to new ways to improve our future agriculture, to create products with high nutritional value, to obtain soils and waters that are less contaminated, and lastly, to increase human health.

Funding: This work was supported by the Ministry of Economy and Competitiveness from Spain (Grant No. PGC2018-09573-B-100) to R.M.R (Murcia, Spain) and by the Ministry of Science, Innovation and Universities of Spain (Grant No. FPU16/05265) to M.L-D. (Murcia, Spain).

Acknowledgments: We sincerely acknowledge Mario G. Fon for proof-reading the manuscript. All authors declare no commercial, industrial links or affiliations.

Conflicts of Interest: The authors declare no conflict of interest.

\section{References}

1. Edelstein, M.; Ben-Hur, M. Heavy metals and metalloids: Sources, risks and strategies to reduce their accumulation in horticultural crops. Sci. Hortic. 2018, 234, 431-444. [CrossRef]

2. Arnao, M.B.; Hernández-Ruiz, J. Role of Melatonin to Enhance Phytoremediation Capacity. Appl. Sci. 2019, 9, 5293. [CrossRef]

3. Sheoran, A.; Sheoran, V. Heavy metal removal mechanism of acid mine drainage in wetlands: A critical review. Miner. Eng. 2006, 19, 105-116. [CrossRef] 
4. Dhiman, S.S.; Selvaraj, C.; Li, J.; Singh, R.; Zhao, X.; Kim, D.; Kim, J.Y.; Kang, Y.C.; Lee, J.-K. Phytoremediation of metalcontaminated soils by the hyperaccumulator canola (Brassica napus L.) and the use of its biomass for ethanol production. Fuel 2016, 183, 107-114. [CrossRef]

5. Dou, X.; Dai, H.; Skuza, L.; Wei, S. Strong accumulation capacity of hyperaccumulator Solanum nigrum L. for low or insoluble Cd compounds in soil and its implication for phytoremediation. Chemosphere 2020, 260, 127564. [CrossRef]

6. Zhong, L.; Lin, L.; Liao, M.; Wang, J.; Tang, Y.; Sun, G.; Liang, D.; Xia, H.; Wang, X.; Zhang, H.; et al. Phytoremediation potential of Pterocypsela laciniata as a cadmium hyperaccumulator. Environ. Sci. Pollut. Res. 2019, 26, 13311-13319. [CrossRef] [PubMed]

7. Back, K.; Tan, D.-X.; Reiter, R.J. Melatonin biosynthesis in plants: Multiple pathways catalyze tryptophan to melatonin in the cytoplasm or chloroplasts. J. Pineal Res. 2016, 61, 426-437. [CrossRef]

8. Wang, L.; Feng, C.; Zheng, X.; Guo, Y.; Zhou, F.; Shan, D.; Liu, X.; Kong, J. Plant mitochondria synthesize melatonin and enhance the tolerance of plants to drought stress. J. Pineal Res. 2017, 63, e12429. [CrossRef]

9. Debnath, B.; Islam, W.; Li, M.; Sun, Y.; Lu, X.; Mitra, S.; Hussain, M.; Liu, S.; Qiu, D. Melatonin Mediates Enhancement of Stress Tolerance in Plants. Int. J. Mol. Sci. 2019, 20, 1040. [CrossRef]

10. Erland, L.A.E.; Murch, S.J.; Reiter, R.J.; Saxena, P.K. A New Balancing Act: The Many Roles of Melatonin and Serotonin in Plant Growth and Development. Plant Signal. Behav. 2015, 10, e1096469. [CrossRef] [PubMed]

11. Ma, Y.; Jiao, J.; Fan, X.; Sun, H.; Zhang, Y.; Jiang, J.; Liu, C. Endophytic Bacterium Pseudomonas fluorescens RG11 May Transform Tryptophan to Melatonin and Promote Endogenous Melatonin Levels in the Roots of Four Grape Cultivars. Front. Plant Sci. 2017, 7, 305. [CrossRef]

12. Zhang, N.; Sun, Q.; Zhang, H.; Cao, Y.; Weeda, S.; Ren, S.; Guo, Y.-D. Roles of Melatonin in Abiotic Stress Resistance in Plants. J. Exp. Bot. 2015, 66, 647-656. [CrossRef] [PubMed]

13. Arnao, M.B.; Hernández-Ruiz, J. Melatonin: Plant growth regulator and/or biostimulator during stress? Trends Plant Sci. 2014, 19, 789-797. [CrossRef] [PubMed]

14. Kul, R.; Esringü, A.; Dadasoglu, E.; Sahin, Üstün; Turan, M.; Örs, S.; Ekinci, M.; Agar, G.; Yildirim, E. Melatonin: Role in Increasing Plant Tolerance in Abiotic Stress Conditions. Abiotic Biotic Stress Plants 2019. [CrossRef]

15. Nawaz, M.A.; Huang, Y.; Bie, Z.; Ahmed, W.; Reiter, R.J.; Niu, M.; Hameed, S. Melatonin: Current Status and Future Perspectives in Plant Science. Front. Plant Sci. 2016, 6, 1230. [CrossRef] [PubMed]

16. Pardo-Hernández, M.; López-Delacalle, M.; Rivero, R. ROS and NO Regulation by Melatonin under Abiotic Stress in Plants. Antioxidants 2020, 9, 1078. [CrossRef]

17. Arnao, M.B.; Hernández-Ruiz, J. Functions of melatonin in plants: A review. J. Pineal Res. 2015, 59, 133-150. [CrossRef]

18. Wang, Y.; Reiter, R.J.; Chan, Z. Phytomelatonin: A universal abiotic stress regulator. J. Exp. Bot. 2017, 69, 963-974. [CrossRef]

19. Tan, D.-X.; Manchester, L.C.; Helton, P.; Reiter, R.J. Phytoremediative Capacity of Plants Enriched with Melatonin. Plant Signal. Behav. 2007, 2, 514-516. [CrossRef]

20. Posmyk, M.M.; Kuran, H.; Marciniak, K.; Janas, K.M. Presowing seed treatment with melatonin protects red cabbage seedlings against toxic copper ion concentrations. J. Pineal Res. 2008, 45, 24-31. [CrossRef]

21. Tan, D.; Manchester, L.C.; Di Mascio, P.; Martinez, G.R.; Prado, F.M.; Reiter, R.J. Novel rhythms of N 1 -acetyl-N 2 -formyl5-methoxykynuramine and its precursor melatonin in water hyacinth: Importance for phytoremediation. FASEB J. 2007, 21, 1724-1729. [CrossRef] [PubMed]

22. Kanwar, M.K.; Yu, J.; Zhou, J. Phytomelatonin: Recent advances and future prospects. J. Pineal Res. 2018, 65, e12526. [CrossRef]

23. Zhu, J.-K. Abiotic Stress Signaling and Responses in Plants. Cell 2016, 167, 313-324. [CrossRef]

24. Nagajyoti, P.C.; Lee, K.D.; Sreekanth, T.V.M. Heavy metals, occurrence and toxicity for plants: A review. Environ. Chem. Lett. 2010, 8, 199-216. [CrossRef]

25. Pourrut, B.; Shahid, M.; Dumat, C.; Winterton, P.; Pinelli, E. Lead Uptake, Toxicity, and Detoxification in Plants. In Reviews of Environmental Contamination and Toxicology; Whitacre, D.M., Ed.; Springer: New York, NY, USA, 2011; Volume 213, pp. 113-136. ISBN 978-1-4419-9860-6.

26. Tran, T.A.; Popova, L.P. Functions and Toxicity of Cadmium in Plants: Recent Advances and Future Prospects. Turk. J. Bot. 2013, 37, 1-13.

27. Burkhead, J.L.; Reynolds, K.A.G.; Abdel-Ghany, S.E.; Cohu, C.M.; Pilon, M. Copper homeostasis. New Phytol. 2009, 182, 799-816. [CrossRef] [PubMed]

28. Kumar, R.; Mehrotra, N.K.; Nautiyal, B.D.; Kumar, P.; Singh, P.K. Effect of copper on growth, yield and concentration of Fe, Mn, $\mathrm{Zn}$ and $\mathrm{Cu}$ in wheat plants (Triticum aestivum L.). J. Environ. Biol. 2009, 30, 485-488. [PubMed]

29. Broadley, M.R.; White, P.J.; Hammond, J.P.; Zelko, I.; Lux, A. Zinc in plants. New Phytol. 2007, 173, 677-702. [CrossRef] [PubMed]

30. Al-Huqail, A.A.; Khan, M.N.; Ali, H.M.; Siddiqui, M.H.; Al-Huqail, A.A.; AlZuaibr, F.M.; Al-Muwayhi, M.A.; Marraiki, N.; Al-Humaid, L. Exogenous melatonin mitigates boron toxicity in wheat. Ecotoxicol. Environ. Saf. 2020, 201, 110822. [CrossRef] [PubMed]

31. Day, S.; Aasim, M. Role of Boron in Growth and Development of Plant: Deficiency and Toxicity Perspective. In Plant Micronutrients: Deficiency and Toxicity Management; Aftab, T., Hakeem, K.R., Eds.; Springer International Publishing: Cham, Switzerland, 2020; pp. 435-453. ISBN 978-3-030-49856-6.

32. Kochian, L.V.; Piñeros, M.A.; Liu, J.; Magalhaes, J.V. Plant Adaptation to Acid Soils: The Molecular Basis for Crop Aluminum Resistance. Annu. Rev. Plant Biol. 2015, 66, 571-598. [CrossRef] [PubMed] 
33. Ma, J.F. Syndrome of Aluminum Toxicity and Diversity of Aluminum Resistance in Higher Plants. Int. Rev. Cytol. 2007, 264, 225-252. [CrossRef]

34. Yamamoto, Y.; Kobayashi, Y.; Devi, S.R.; Rikiishi, S.; Matsumoto, H. Aluminum Toxicity Is Associated with Mitochondrial Dysfunction and the Production of Reactive Oxygen Species in Plant Cells. Plant Physiol. 2002, 128, 63-72. [CrossRef]

35. Imtiaz, M.; Rizwan, M.S.; Xiong, S.; Li, H.; Ashraf, M.; Shahzad, S.M.; Shahzad, M.; Tu, S. Vanadium, recent advancements and research prospects: A review. Environ. Int. 2015, 80, 79-88. [CrossRef] [PubMed]

36. Küpper, H.; Andresen, E. Mechanisms of metal toxicity in plants. Metallomics 2016, 8, 269-285. [CrossRef]

37. Maheshwari, R.; Dubey, R.S. Nickel-induced oxidative stress and the role of antioxidant defence in rice seedlings. Plant Growth Regul. 2009, 59, 37-49. [CrossRef]

38. Yusuf, M.; Fariduddin, Q.; Hayat, S.; Ahmad, A. Nickel: An Overview of Uptake, Essentiality and Toxicity in Plants. Bull. Environ. Contam. Toxicol. 2011, 86,1-17. [CrossRef]

39. Abbas, G.; Murtaza, B.; Niazi, N.K.; Shahid, M.; Niazi, N.K.; Khan, M.I.; Amjad, M.; Hussain, M.; Natasha. Arsenic Uptake, Toxicity, Detoxification, and Speciation in Plants: Physiological, Biochemical, and Molecular Aspects. Int. J. Environ. Res. Public Health 2018, 15, 59. [CrossRef] [PubMed]

40. Chandrakar, V.; Dubey, A.; Keshavkant, S. Modulation of antioxidant enzymes by salicylic acid in arsenic exposed Glycine max L. J. Soil Sci. Plant Nutr. 2016, 16, 662-676. [CrossRef]

41. Samanta, S.; Banerjee, A.; Roychoudhury, A. Melatonin application differentially modulates the enzymes associated with antioxidative machinery and ascorbate-glutathione cycle during arsenate exposure in indica rice varieties. Plant Biol. 2020. [CrossRef] [PubMed]

42. Gomes, M.A.D.C.; Hauser-Davis, R.A.; Suzuki, M.S.; Vitória, A.P. Plant chromium uptake and transport, physiological effects and recent advances in molecular investigations. Ecotoxicol. Environ. Saf. 2017, 140, 55-64. [CrossRef] [PubMed]

43. Sun, C.; Liu, L.; Wang, L.; Li, B.; Jin, C.; Lin, X. Melatonin: A master regulator of plant development and stress responses. J. Integr. Plant Biol. 2021, 63, 126-145. [CrossRef]

44. Xie, C.; Xiong, X.; Huang, Z.; Sun, L.; Ma, J.; Cai, S.; Yu, F.; Zhong, W.; Chen, S.; Li, X. Exogenous melatonin improves lead tolerance of bermudagrass through modulation of the antioxidant defense system. Int. J. Phytoremediation 2018, 20, $1408-1417$. [CrossRef] [PubMed]

45. Mohamed, H.A.; Moussa, H.R.; Rgab, M.H.E.-D.S. Does Exogenous Application of Melatonin Ameliorate Lead Toxicity in Eruca vesicaria Plants? Egypt. J. Bot. 2020, 61, 33-44. [CrossRef]

46. Gu, Q.; Chen, Z.; Yu, X.; Cui, W.; Pan, J.; Zhao, G.; Xu, S.; Wang, R.; Shen, W. Melatonin confers plant tolerance against cadmium stress via the decrease of cadmium accumulation and reestablishment of microRNA-mediated redox homeostasis. Plant Sci. 2017, 261, 28-37. [CrossRef] [PubMed]

47. Hasan, K.; Ahammed, G.J.; Sun, S.; Li, M.; Yin, H.; Zhou, J. Melatonin Inhibits Cadmium Translocation and Enhances Plant Tolerance by Regulating Sulfur Uptake and Assimilation in Solanum lycopersicum L. J. Agric. Food Chem. 2019, 67, 10563-10576. [CrossRef]

48. Hasan, K.; Ahammed, G.J.; Yin, L.; Shi, K.; Xia, X.; Zhou, Y.; Yu, J.; Zhou, J. Melatonin mitigates cadmium phytotoxicity through modulation of phytochelatins biosynthesis, vacuolar sequestration, and antioxidant potential in Solanum lycopersicum L. Front. Plant Sci. 2015, 6, 601. [CrossRef]

49. Umapathi, M. Cadmium Induced Stress Mitigation in Tomato by Exogenous Melatonin. Int. J. Pure Appl. Biosci. 2018, 6, 903-909. [CrossRef]

50. Kaya, C.; Okant, M.; Ugurlar, F.; Alyemeni, M.N.; Ashraf, M.; Ahmad, P. Melatonin-mediated nitric oxide improves tolerance to cadmium toxicity by reducing oxidative stress in wheat plants. Chemosphere 2019, 225, 627-638. [CrossRef]

51. Ni, J.; Wang, Q.; Shah, F.A.; Liu, W.; Wang, D.; Huang, S.; Fu, S.; Wu, L. Exogenous Melatonin Confers Cadmium Tolerance by Counterbalancing the Hydrogen Peroxide Homeostasis in Wheat Seedlings. Molecules 2018, 23, 799. [CrossRef]

52. Lin, L.; Li, J.; Chen, F.; Liao, M.; Tang, Y.; Liang, N.; Xia, H.; Lai, Y.; Wang, X.; Chen, C.; et al. Effects of melatonin on the growth and cadmium characteristics of Cyphomandra betacea seedlings. Environ. Monit. Assess. 2018, 190, 119. [CrossRef] [PubMed]

53. Tang, Y.; Lin, L.; Xie, Y.; Liu, J.; Sun, G.; Li, H.; Liao, M.; Wang, Z.; Liang, D.; Xia, H.; et al. Melatonin affects the growth and cadmium accumulation of Malachium aquaticum and Galinsoga parviflora. Int. J. Phytoremediation 2018, 20, 295-300. [CrossRef] [PubMed]

54. Xiang, G.; Lin, L.; Liao, M.; Tang, Y.; Liang, D.; Xia, H.; Wang, J.; Wang, X.; Sun, G.; Zhang, H.; et al. Effects of melatonin on cadmium accumulation in the accumulator plant Perilla frutescens. Chem. Ecol. 2019, 35, 553-562. [CrossRef]

55. Lee, H.-Y.; Back, K. Cadmium Disrupts Subcellular Organelles, Including Chloroplasts, Resulting in Melatonin Induction in Plants. Molecules 2017, 22, 1791. [CrossRef] [PubMed]

56. Lee, K.; Back, K. Overexpression of rice serotonin N-acetyltransferase1 in transgenic rice plants confers resistance to cadmium and senescence and increases grain yield. J. Pineal Res. 2017, 62, e12392. [CrossRef] [PubMed]

57. Reiter, R.J.; Tan, D.-X.; Zhou, Z.; Cruz, M.H.C.; Fuentes-Broto, L.; Galano, A. Phytomelatonin: Assisting Plants to Survive and Thrive. Molecules 2015, 20, 7396-7437. [CrossRef]

58. Tal, O.; Haim, A.; Harel, O.; Gerchman, Y. Melatonin as an antioxidant and its semi-lunar rhythm in green macroalga Ulva sp. J. Exp. Bot. 2011, 62, 1903-1910. [CrossRef] 
59. Tousi, S.; Zoufan, P.; Ghahfarrokhie, A.R. Alleviation of cadmium-induced phytotoxicity and growth improvement by exogenous melatonin pretreatment in mallow (Malva parviflora) plants. Ecotoxicol. Environ. Saf. 2020, 206, 111403. [CrossRef]

60. Asif, M.; Pervez, A.; Irshad, U.; Mehmood, Q.; Ahmad, R. Melatonin and Plant Growth-Promoting Rhizobacteria Alleviate the Cadmium and Arsenic Stresses and Increase the Growthof Spinacia Oleracea L. Plant Soil Environ. 2020, 66, 234-241. [CrossRef]

61. Wang, T.; Song, J.; Liu, Z.; Liu, Z.; Cui, J. Melatonin alleviates cadmium toxicity by reducing nitric oxide accumulation and IRT1 expression in Chinese cabbage seedlings. Environ. Sci. Pollut. Res. 2021, 28, 15394-15405. [CrossRef]

62. Sami, A.; Shah, F.A.; Abdullah, M.; Zhou, X.; Yan, Y.; Zhu, Z.; Zhou, K. Melatonin mitigates cadmium and aluminium toxicity through modulation of antioxidant potential in Brassica napus L. Plant Biol. 2020, 22, 679-690. [CrossRef]

63. Shah, A.A.; Ahmed, S.; Ali, A.; Yasin, N.A. 2-Hydroxymelatonin mitigates cadmium stress in Cucumis sativus seedlings: Modulation of antioxidant enzymes and polyamines. Chemosphere 2020, 243, 125308. [CrossRef] [PubMed]

64. Wu, S.; Wang, Y.; Zhang, J.; Gong, X.; Zhang, Z.; Sun, J.; Chen, X.; Wang, Y. Exogenous Melatonin Improves Physiological Characteristics and Promotes Growth of Strawberry Seedlings Under Cadmium Stress. Hortic. Plant J. 2021, 7, 13-22. [CrossRef]

65. Cao, Y.-Y.; Qi, C.-D.; Li, S.; Wang, Z.; Wang, X.; Wang, J.; Ren, S.; Li, X.; Zhang, N.; Guo, Y.-D. Melatonin Alleviates Copper Toxicity via Improving Copper Sequestration and ROS Scavenging in Cucumber. Plant Cell Physiol. 2018, 60, 562-574. [CrossRef]

66. Zuo, Z.; Sun, L.; Wang, T.; Miao, P.; Zhu, X.; Liu, S.; Song, F.; Mao, H.; Li, X. Melatonin Improves the Photosynthetic Carbon Assimilation and Antioxidant Capacity in Wheat Exposed to Nano-ZnO Stress. Molecules 2017, 22, 1727. [CrossRef]

67. Nawaz, M.A.; Jiao, Y.; Chen, C.; Shireen, F.; Zheng, Z.; Imtiaz, M.; Bie, Z.; Huang, Y. Melatonin pretreatment improves vanadium stress tolerance of watermelon seedlings by reducing vanadium concentration in the leaves and regulating melatonin biosynthesis and antioxidant-related gene expression. J. Plant Physiol. 2018, 220, 115-127. [CrossRef]

68. Jahan, M.S.; Guo, S.; Baloch, A.R.; Sun, J.; Shu, S.; Wang, Y.; Ahammed, G.J.; Kabir, K.; Roy, R. Melatonin alleviates nickel phytotoxicity by improving photosynthesis, secondary metabolism and oxidative stress tolerance in tomato seedlings. Ecotoxicol. Environ. Saf. 2020, 197, 110593. [CrossRef]

69. Seleiman, M.F.; Ali, S.; Refay, Y.; Rizwan, M.; Alhammad, B.A.; El-Hendawy, S.E. Chromium resistant microbes and melatonin reduced $\mathrm{Cr}$ uptake and toxicity, improved physio-biochemical traits and yield of wheat in contaminated soil. Chemosphere 2020, 250, 126239. [CrossRef]

70. Ayyaz, A.; Amir, M.; Umer, S.; Iqbal, M.; Bano, H.; Gul, H.S.; Noor, Y.; Kanwal, A.; Khalid, A.; Javed, M.; et al. Melatonin induced changes in photosynthetic efficiency as probed by OJIP associated with improved chromium stress tolerance in canola (Brassica napus L.). Heliyon 2020, 6, e04364. [CrossRef]

71. Ayyaz, A.; Farooq, M.A.; Kanwal, A.; Aslam, M.; Iqbal, M.; Manzoor, A.; Khalid, A.; Umer, S.; Bano, H.; Sameen, S.; et al. Differential responses of exogenous melatonin on growth, photosynthesis and antioxidant defence system in two Brassica napus L.cultivars under chromium stress. Int. J. Environ. Agric. Biotechnol. 2020, 5, 397-411. [CrossRef]

72. Sharma, A.; Wang, J.; Xu, D.; Tao, S.; Chong, S.; Yan, D.; Li, Z.; Yuan, H.; Zheng, B. Melatonin regulates the functional components of photosynthesis, antioxidant system, gene expression, and metabolic pathways to induce drought resistance in grafted Carya cathayensis plants. Sci. Total. Environ. 2020, 713, 136675. [CrossRef] [PubMed]

73. Hu, Z.; Fu, Q.; Zheng, J.; Zhang, A.; Wang, H. Transcriptomic and metabolomic analyses reveal that melatonin promotes melon root development under copper stress by inhibiting jasmonic acid biosynthesis. Hortic. Res. 2020, 7, 1-15. [CrossRef] [PubMed]

74. Namdjoyan, S.; Soorki, A.A.; Elyasi, N.; Kazemi, N.; Simaei, M. Melatonin alleviates lead-induced oxidative damage in safflower (Carthamus tinctorius L.) seedlings. Ecotoxicology 2019, 29, 108-118. [CrossRef] [PubMed]

75. David, O.A.; Jolayemi, O.L.; Akomolafe, G.F.; Adegoke, M.A. Lead sequestration, immobilization and xylem cavitation in melatonin-primed Amaranthus cruentus. Plant Physiol. Rep. 2021, 26, 162-171. [CrossRef]

76. Nazarian, M.; Ghanati, F. The role of melatonin in reinforcement of antioxidant system of rice plant (Oryza sativa L.) under arsenite toxicity? Plant Physiol. Rep. 2020, 25, 1-10. [CrossRef]

77. Li, M.-Q.; Hasan, K.; Li, C.-X.; Ahammed, G.J.; Xia, X.-J.; Shi, K.; Zhou, Y.-H.; Reiter, R.J.; Yu, J.-Q.; Xu, M.-X.; et al. Melatonin mediates selenium-induced tolerance to cadmium stress in tomato plants. J. Pineal Res. 2016, 61, 291-302. [CrossRef] [PubMed]

78. Goodarzi, A.; Namdjoyan, S.; Soorki, A.A. Effects of exogenous melatonin and glutathione on zinc toxicity in safflower (Carthamus tinctorius L.) seedlings. Ecotoxicol. Environ. Saf. 2020, 201, 110853. [CrossRef]

79. Siddiqui, M.H.; Alamri, S.; Khan, M.N.; Corpas, F.J.; Al-Amri, A.A.; Alsubaie, Q.D.; Ali, H.M.; Kalaji, H.M.; Ahmad, P. Melatonin and calcium function synergistically to promote the resilience through ROS metabolism under arsenic-induced stress. J. Hazard. Mater. 2020, 398, 122882. [CrossRef]

80. Zhang, X.; Zhang, H.; Zhang, H.; Tang, M. Exogenous Melatonin Application Enhances Rhizophagus irregularis Symbiosis and Induces the Antioxidant Response of Medicago truncatula Under Lead Stress. Front. Microbiol. 2020, 11, 516. [CrossRef]

81. Baxter, A.; Mittler, R.; Suzuki, N. ROS as key players in plant stress signalling. J. Exp. Bot. 2014, 65, 1229-1240. [CrossRef]

82. Sharma, A.; Zheng, B. Melatonin Mediated Regulation of Drought Stress: Physiological and Molecular Aspects. Plants 2019, 8, 190. [CrossRef]

83. Halliwell, B.; Gutteridge, J.M.C. Oxygen toxicity, oxygen radicals, transition metals and disease. Biochem. J. 1984, $219,1-14$. [CrossRef]

84. Ortega-Villasante, C.; Rellán-Álvarez, R.; Del Campo, F.F.; Carpena-Ruiz, R.O.; Hernández, L.E. Cellular damage induced by cadmium and mercury in Medicago sativa. J. Exp. Bot. 2005, 56, 2239-2251. [CrossRef] [PubMed] 
85. Schützendübel, A. Plant responses to abiotic stresses: Heavy metal-induced oxidative stress and protection by mycorrhization. J. Exp. Bot. 2002, 53, 1351-1365. [CrossRef] [PubMed]

86. Rodríguez-Serrano, M.; Romero-Puertas, M.C.; Pazmiño, D.M.; Testillano, P.S.; Risueño, M.C.; del Río, L.A.; Sandalio, L.M. Cellular Response of Pea Plants to Cadmium Toxicity: Cross Talk between Reactive Oxygen Species, Nitric Oxide, and Calcium. Plant Physiol. 2009, 150, 229-243. [CrossRef] [PubMed]

87. Romero-Puertas, M.C.; Rodriguez-Serrano, M.; Corpas, F.J.; Gomez, M.; Del Rio, L.A.; Sandalio, L.M. Cadmium-induced subcellular accumulation of $\mathrm{O}_{2}$-- and $\mathrm{H}_{2} \mathrm{O}_{2}$ in pea leaves. Plant Cell Environ. 2004, 27, 1122-1134. [CrossRef]

88. Ortega-Villasante, C.; Hernández, L.E.; Rellán-Álvarez, R.; Del Campo, F.F.; Carpena-Ruiz, R.O. Rapid alteration of cellular redox homeostasis upon exposure to cadmium and mercury in alfalfa seedlings. New Phytol. 2007, 176, 96-107. [CrossRef] [PubMed]

89. Yuan, H.-M.; Liu, W.-C.; Jin, Y.; Lu, Y.-T. Role of ROS and auxin in plant response to metal-mediated stress. Plant Signal. Behav. 2013, 8, e24671. [CrossRef] [PubMed]

90. Tan, D.-X.; Reiter, R.; Manchester, L.; Yan, M.-T.; El-Sawi, M.; Sainz, R.; Mayo, J.; Kohen, R.; Allegra, M.; Hardelan, R. Chemical and Physical Properties and Potential Mechanisms: Melatonin as a Broad Spectrum Antioxidant and Free Radical Scavenger. Curr. Top. Med. Chem. 2002, 2, 181-197. [CrossRef]

91. Kaur, H.; Mukherjee, S.; Baluska, F.; Bhatla, S.C. Regulatory roles of serotonin and melatonin in abiotic stress tolerance in plants. Plant Signal. Behav. 2015, 10, e1049788. [CrossRef]

92. Arnao, M.B.; Hernández-Ruiz, J. Melatonin: A New Plant Hormone and/or a Plant Master Regulator? Trends Plant Sci. 2019, 24, 38-48. [CrossRef] [PubMed]

93. Khan, A.; Numan, M.; Khan, A.L.; Lee, I.-J.; Imran, M.; Asaf, S.; Al-Harrasi, A. Melatonin: Awakening the Defense Mechanisms during Plant Oxidative Stress. Plants 2020, 9, 407. [CrossRef]

94. Kaur, H.; Bhatla, S.C. Melatonin and nitric oxide modulate glutathione content and glutathione reductase activity in sunflower seedling cotyledons accompanying salt stress. Nitric Oxide 2016, 59, 42-53. [CrossRef] [PubMed]

95. Liu, N.; Jin, Z.; Wang, S.; Gong, B.; Wen, D.; Wang, X.; Wei, M.; Shi, Q. Sodic alkaline stress mitigation with exogenous melatonin involves reactive oxygen metabolism and ion homeostasis in tomato. Sci. Hortic. 2015, 181, 18-25. [CrossRef]

96. Yu, Y.; Wang, A.; Li, X.; Kou, M.; Wang, W.; Chen, X.; Xu, T.; Zhu, M.; Ma, D.; Li, Z.; et al. Melatonin-Stimulated Triacylglycerol Breakdown and Energy Turnover under Salinity Stress Contributes to the Maintenance of Plasma Membrane $\mathrm{H}^{+}-\mathrm{ATPase}$ Activity and $\mathrm{K}^{+} / \mathrm{Na}^{+}$Homeostasis in Sweet Potato. Front. Plant Sci. 2018, 9, 256. [CrossRef] [PubMed]

97. Ahammed, G.J.; Xu, W.; Liu, A.; Chen, S. Endogenous melatonin deficiency aggravates high temperature-induced oxidative stress in Solanum lycopersicum L. Environ. Exp. Bot. 2019, 161, 303-311. [CrossRef]

98. Jahan, M.S.; Shu, S.; Wang, Y.; Chen, Z.; He, M.; Tao, M.; Sun, J.; Guo, S. Melatonin alleviates heat-induced damage of tomato seedlings by balancing redox homeostasis and modulating polyamine and nitric oxide biosynthesis. BMC Plant Biol. 2019, 19, 1-16. [CrossRef]

99. Li, Z.-G.; Xu, Y.; Bai, L.-K.; Zhang, S.-Y.; Wang, Y. Melatonin enhances thermotolerance of maize seedlings (Zea mays L.) by modulating antioxidant defense, methylglyoxal detoxification, and osmoregulation systems. Protoplasma 2018, 256, 471-490. [CrossRef]

100. Liang, D.; Gao, F.; Ni, Z.; Lin, L.; Deng, Q.; Tang, Y.; Wang, X.; Luo, X.; Xia, H. Melatonin Improves Heat Tolerance in Kiwifruit Seedlings through Promoting Antioxidant Enzymatic Activity and Glutathione S-Transferase Transcription. Molecules 2018, 23, 584. [CrossRef] [PubMed]

101. Zhao, H.; Ye, L.; Wang, Y.; Zhou, X.; Yang, J.; Wang, J.; Cao, K.; Zou, Z. Melatonin Increases the Chilling Tolerance of Chloroplast in Cucumber Seedlings by Regulating Photosynthetic Electron Flux and the Ascorbate-Glutathione Cycle. Front. Plant Sci. 2016, 7, 1814. [CrossRef]

102. Dawood, M.G.; Sadak, M.S. Physiological Role of Glycinebetaine in Alleviating the Deleterious Effects of Drought Stress on Canola Plants (Brassica napus L.). Middle East J. Agric. Res 2014, 3, 943-954.

103. Kim, T.-Y.; Jo, M.-H.; Hong, J.-H. Protective Effect of Nitric Oxide against Oxidative Stress under UV-B Radiation in Maize Leaves. J. Environ. Sci. Int. 2010, 19, 1323-1334. [CrossRef]

104. Lee, H.Y.; Back, K. Melatonin induction and its role in high light stress tolerance in Arabidopsis thaliana. J. Pineal Res. 2018, 65, e12504. [CrossRef]

105. Zhan, H.; Nie, X.; Zhang, T.; Li, S.; Wang, X.; Du, X.; Tong, W.; Song, W. Melatonin: A Small Molecule but Important for Salt Stress Tolerance in Plants. Int. J. Mol. Sci. 2019, 20, 709. [CrossRef]

106. Okant, M.; Kaya, C. The role of endogenous nitric oxide in melatonin-improved tolerance to lead toxicity in maize plants. Environ. Sci. Pollut. Res. 2019, 26, 11864-11874. [CrossRef] [PubMed]

107. Zhang, J.; Zeng, B.; Mao, Y.; Kong, X.; Wang, X.; Yang, Y.; Zhang, J.; Xu, J.; Rengel, Z.; Chen, Q. Melatonin alleviates aluminium toxicity through modulating antioxidative enzymes and enhancing organic acid anion exudation in soybean. Funct. Plant Biol. 2017, 44, 961-968. [CrossRef]

108. Sun, C.; Lv, T.; Huang, L.; Liu, X.; Jin, C.; Lin, X. Melatonin ameliorates aluminum toxicity through enhancing aluminum exclusion and reestablishing redox homeostasis in roots of wheat. J. Pineal Res. 2020, 68, e12642. [CrossRef] [PubMed]

109. Farouk, S.; Al-Amri, S.M. Exogenous melatonin-mediated modulation of arsenic tolerance with improved accretion of secondary metabolite production, activating antioxidant capacity and improved chloroplast ultrastructure in rosemary herb. Ecotoxicol. Environ. Saf. 2019, 180, 333-347. [CrossRef] [PubMed] 
110. Shah, A.A.; Ahmed, S.; Yasin, N.A. 2-Hydroxymelatonin induced nutritional orchestration in Cucumis sativus under cadmium toxicity: Modulation of non-enzymatic antioxidants and gene expression. Int. J. Phytoremediation 2020, 22, 497-507. [CrossRef] [PubMed]

111. Nabaei, M.; Amooaghaie, R. Nitric oxide is involved in the regulation of melatonin-induced antioxidant responses in Catharanthus roseus roots under cadmium stress. Botany 2019, 97, 681-690. [CrossRef]

112. Nabaei, M.; Amooaghaie, R. Interactive Effect of Melatonin and Sodium Nitroprusside on Seed Germination and Seedling Growth of Catharanthus roseus under Cadmium Stress. Russ. J. Plant Physiol. 2019, 66, 128-139. [CrossRef]

113. Sarafi, E.; Tsouvaltzis, P.; Chatzissavvidis, C.; Siomos, A.; Therios, I. Melatonin and resveratrol reverse the toxic effect of high boron (B) and modulate biochemical parameters in pepper plants (Capsicum annuum L.). Plant Physiol. Biochem. 2017, 112, 173-182. [CrossRef]

114. Verkleij, J.A.C.; Prast, J.E. Cadmium tolerance and co-tolerance in Silene vulgaris (Moench.) Garcke [= S. cucubalus (L.) Wib.]. New Phytol. 1989, 111, 637-645. [CrossRef]

115. Zhu, Y.; Yu, H.; Wang, J.; Fang, W.; Yuan, J.; Yang, Z. Heavy Metal Accumulations of 24 Asparagus Bean Cultivars Grown in Soil Contaminated with Cd Alone and with Multiple Metals (Cd, Pb, and Zn). J. Agric. Food Chem. 2007, 55, 1045-1052. [CrossRef] [PubMed]

116. An, P.; Li, X.; Zheng, Y.; Matsuura, A.; Abe, J.; Eneji, A.E.; Tanimoto, E.; Inanaga, S. Effects of NaCl on Root Growth and Cell Wall Composition of Two Soya bean Cultivars with Contrasting Salt Tolerance. J. Agron. Crop. Sci. 2014, 200, 212-218. [CrossRef]

117. Eshghizadeh , H.R.; Kafi, M.; Nezami, A.; Khoshgoftarmanesh, A. Studies on the Role of Root Morphology Attribution in Salt Tolerance of Blue-Panicgrass (Panicum Antidotale Retz.) Using Artificial Neural Networks (ANN). Res. Crops 2012, 13, 534-544.

118. Sharma, S.S.; Dietz, K.-J. The significance of amino acids and amino acid-derived molecules in plant responses and adaptation to heavy metal stress. J. Exp. Bot. 2006, 57, 711-726. [CrossRef] [PubMed]

119. Wali, M.; Fourati, E.; Hmaeid, N.; Ghabriche, R.; Poschenrieder, C.; Abdelly, C.; Ghnaya, T. NaCl alleviates Cd toxicity by changing its chemical forms of accumulation in the halophyte Sesuvium portulacastrum. Environ. Sci. Pollut. Res. 2015, 22, 10769-10777. [CrossRef]

120. Xin, J.; Huang, B. Subcellular Distribution and Chemical Forms of Cadmium in Two Hot Pepper Cultivars Differing in Cadmium Accumulation. J. Agric. Food Chem. 2014, 62, 508-515. [CrossRef] [PubMed]

121. Xu, Z.-M.; Li, Q.-S.; Yang, P.; Ye, H.-J.; Chen, Z.-S.; Guo, S.-H.; Wang, L.-L.; He, B.-Y.; Zeng, E.Y. Impact of osmoregulation on the differences in $\mathrm{Cd}$ accumulation between two contrasting edible amaranth cultivars grown on Cd-polluted saline soils. Environ. Pollut. 2017, 224, 89-97. [CrossRef]

122. Moussa, H.R.; Algamal, S.M.A. Does Exogenous Application of Melatonin Ameliorate Boron Toxicity in Spinach Plants? Int. J. Veg. Sci. 2016, 23, 233-245. [CrossRef]

123. Gong, X.; Shi, S.; Dou, F.; Song, Y.; Ma, F. Exogenous Melatonin Alleviates Alkaline Stress in Malus hupehensis Rehd by Regulating the Biosynthesis of Polyamines. Molecules 2017, 22, 1542. [CrossRef]

124. Zhang, Q.; Liu, X.; Zhang, Z.; Liu, N.; Li, D.; Hu, L. Melatonin Improved Waterlogging Tolerance in Alfalfa (Medicago sativa) by Reprogramming Polyamine and Ethylene Metabolism. Front. Plant Sci. 2019, 10. [CrossRef]

125. Aghdam, M.S.; Luo, Z.; Jannatizadeh, A.; Sheikh-Assadi, M.; Sharafi, Y.; Farmani, B.; Fard, J.R.; Razavi, F. Employing exogenous melatonin applying confers chilling tolerance in tomato fruits by upregulating ZAT2/6/12 giving rise to promoting endogenous polyamines, proline, and nitric oxide accumulation by triggering arginine pathway activity. Food Chem. 2019, 275, 549-556. [CrossRef] [PubMed]

126. Kobylińska, A.; Posmyk, M.M. Melatonin restricts Pb-induced PCD by enhancing BI-1 expression in tobacco suspension cells. BioMetals 2016, 29, 1059-1074. [CrossRef] [PubMed]

127. Wang, M.; Duan, S.; Zhou, Z.; Chen, S.; Wang, D. Foliar spraying of melatonin confers cadmium tolerance in Nicotiana tabacum L. Ecotoxicol. Environ. Saf. 2019, 170, 68-76. [CrossRef] [PubMed]

128. Xu, L.; Zhang, F.; Tang, M.; Wang, Y.; Dong, J.; Ying, J.; Chen, Y.; Hu, B.; Li, C.; Liu, L. Melatonin confers cadmium tolerance by modulating critical heavy metal chelators and transporters in radish plants. J. Pineal Res. 2020, 69, e12659. [CrossRef] [PubMed]

129. Li, X.; Ahammed, G.J.; Zhang, X.-N.; Zhang, L.; Yan, P.; Zhang, L.-P.; Fu, J.-Y.; Han, W.-Y. Melatonin-mediated regulation of anthocyanin biosynthesis and antioxidant defense confer tolerance to arsenic stress in Camellia sinensis L. J. Hazard. Mater. 2021, 403, 123922. [CrossRef]

130. Baudouin, E.; Hancock, J.T. Nitric oxide signaling in plants. Front. Plant Sci. 2014, 4, 553. [CrossRef]

131. Palma, J.M.; Freschi, L.; Rodríguez-Ruiz, M.; González-Gordo, S.; Corpas, F.J. Nitric oxide in the physiology and quality of fleshy fruits. J. Exp. Bot. 2019, 70, 4405-4417. [CrossRef] [PubMed]

132. Nieves-Cordones, M.; López-Delacalle, M.; Ródenas, R.; Martínez, V.; Rubio, F.; Rivero, R.M. Critical responses to nutrient deprivation: A comprehensive review on the role of ROS and RNS. Environ. Exp. Bot. 2019, 161, 74-85. [CrossRef]

133. Gow, A.J.; Farkouh, C.R.; Munson, D.A.; Posencheg, M.A.; Ischiropoulos, H. Biological significance of nitric oxide-mediated protein modifications. Am. J. Physiol. Cell. Mol. Physiol. 2004, 287, L262-L268. [CrossRef]

134. Fares, A.; Rossignol, M.; Peltier, J.-B. Proteomics investigation of endogenous S-nitrosylation in Arabidopsis. Biochem. Biophys. Res. Commun. 2011, 416, 331-336. [CrossRef] [PubMed] 
135. Romero-Puertas, M.C.; Campostrini, N.; Mattè, A.; Righetti, P.G.; Perazzolli, M.; Zolla, L.; Roepstorff, P.; Delledonne, M. Proteomic analysis of S-nitrosylated proteins in Arabidopsis thaliana undergoing hypersensitive response. Proteomics 2008, 8, 1459-1469. [CrossRef]

136. Radi, R. Nitric oxide, oxidants, and protein tyrosine nitration. Proc. Natl. Acad. Sci. USA 2004, 101, 4003-4008. [CrossRef]

137. Begara-Morales, J.C.; Sánchez-Calvo, B.; Chaki, M.; Mata-Pérez, C.; Valderrama, R.; Padilla, M.N.; López-Jaramillo, J.; Luque, F.; Corpas, F.J.; Barroso, J.B. Differential molecular response of monodehydroascorbate reductase and glutathione reductase by nitration andS-nitrosylation. J. Exp. Bot. 2015, 66, 5983-5996. [CrossRef]

138. Begara-Morales, J.C.; Sánchez-Calvo, B.; Chaki, M.; Valderrama, R.; Mata-Pérez, C.; López-Jaramillo, J.; Padilla, M.N.; Carreras, A.; Corpas, F.J.; Barroso, J.B. Dual regulation of cytosolic ascorbate peroxidase (APX) by tyrosine nitration and S-nitrosylation. J. Exp. Bot. 2014, 65, 527-538. [CrossRef]

139. Besson-Bard, A.; Pugin, A.; Wendehenne, D. New Insights into Nitric Oxide Signaling in Plants. Annu. Rev. Plant Biol. 2008, 59, 21-39. [CrossRef]

140. Antoniou, C.; Chatzimichail, G.; Xenofontos, R.; Pavlou, J.J.; Panagiotou, E.; Christou, A.; Fotopoulos, V. Melatonin systemically ameliorates drought stress-induced damage in Medicago sativa plants by modulating nitro-oxidative homeostasis and proline metabolism. J. Pineal Res. 2017, 62, e12401. [CrossRef]

141. Arora, D.; Bhatla, S.C. Melatonin and nitric oxide regulate sunflower seedling growth under salt stress accompanying differential expression of $\mathrm{Cu} / \mathrm{Zn}$ SOD and Mn SOD. Free. Radic. Biol. Med. 2017, 106, 315-328. [CrossRef] [PubMed]

142. Kopczak, A.; Korth, H.-G.; De Groot, H.; Kirsch, M. N-nitroso-melatonin releases nitric oxide in the presence of serotonin and its derivatives. J. Pineal Res. 2007, 43, 343-350. [CrossRef] [PubMed]

143. Berchner-Pfannschmidt, U.; Tug, S.; Trinidad, B.; Becker, M.; Oehme, F.; Flamme, I.; Fandrey, J.; Kirsch, M. The impact ofNnitrosomelatonin as nitric oxide donor in cell culture experiments. J. Pineal Res. 2008, 45, 489-496. [CrossRef] [PubMed]

144. Ding, W.; Zhao, Y.; Xu, J.-W.; Zhao, P.; Li, T.; Ma, H.; Reiter, R.J.; Yu, X. Melatonin: A Multifunctional Molecule That Triggers Defense Responses against High Light and Nitrogen Starvation Stress in Haematococcus pluvialis. J. Agric. Food Chem. 2018, 66, 7701-7711. [CrossRef]

145. Kaya, C.; Higgs, D.; Ashraf, M.; Alyemeni, M.N.; Ahmad, P. Integrative roles of nitric oxide and hydrogen sulfide in melatonininduced tolerance of pepper (Capsicum annuum L.) plants to iron deficiency and salt stress alone or in combination. Physiol. Plant. 2019, 168, 256-277. [CrossRef] [PubMed]

146. Liu, N.; Gong, B.; Jin, Z.; Wang, X.; Wei, M.; Yang, F.; Li, Y.; Shi, Q. Sodic alkaline stress mitigation by exogenous melatonin in tomato needs nitric oxide as a downstream signal. J. Plant Physiol. 2015, 186-187, 68-77. [CrossRef]

147. Zhao, G.; Zhao, Y.; Yu, X.; Kiprotich, F.; Han, H.; Guan, R.; Wang, R.; Shen, W. Nitric Oxide Is Required for Melatonin-Enhanced Tolerance against Salinity Stress in Rapeseed (Brassica napus L.) Seedlings. Int. J. Mol. Sci. 2018, 19, 1912. [CrossRef] [PubMed]

148. Nabaei, M.; Amooaghaie, R. Melatonin and nitric oxide enhance cadmium tolerance and phytoremediation efficiency in Catharanthus roseus (L.) G. Don. Environ. Sci. Pollut. Res. 2019, 27, 6981-6994. [CrossRef]

149. Huang, Z.; Xie, W.; Wang, M.; Liu, X.; Ashraf, U.; Qin, D.; Zhuang, M.; Li, W.; Li, Y.; Wang, S.; et al. Response of Rice Genotypes with Differential Nitrate Reductase-Dependent NO Synthesis to Melatonin under ZnO Nanoparticles' (NPs) Stress. Chemosphere 2020, 250, 126337. [CrossRef]

150. Zhang, J.; Li, D.; Wei, J.; Ma, W.; Kong, X.; Rengel, Z.; Chen, Q. Melatonin alleviates aluminum-induced root growth inhibition by interfering with nitric oxide production in Arabidopsis. Environ. Exp. Bot. 2019, 161, 157-165. [CrossRef]

151. Zahedi, S.M.; Hosseini, M.S.; Abadía, J.; Marjani, M. Melatonin foliar sprays elicit salinity stress tolerance and enhance fruit yield and quality in strawberry (Fragaria $\times$ ananassa Duch.). Plant Physiol. Biochem. 2020, 149, 313-323. [CrossRef]

152. Fu, J.; Wu, Y.; Miao, Y.; Xu, Y.; Zhao, E.; Wang, J.; Sun, H.; Liu, Q.; Xue, Y.; Xu, Y.; et al. Improved cold tolerance in Elymus nutans by exogenous application of melatonin may involve ABA-dependent and ABA-independent pathways. Sci. Rep. 2017, 7, 39865. [CrossRef]

153. Siddiqui, M.H.; Alamri, S.; Alsubaie, Q.D.; Ali, H.M.; Ibrahim, A.A.; Alsadon, A. Potential roles of melatonin and sulfur in alleviation of lanthanum toxicity in tomato seedlings. Ecotoxicol. Environ. Saf. 2019, 180, 656-667. [CrossRef]

154. Ulhassan, Z.; Huang, Q.; Gill, R.A.; Ali, S.; Mwamba, T.M.; Ali, B.; Hina, F.; Zhou, W. Protective mechanisms of melatonin against selenium toxicity in Brassica napus: Insights into physiological traits, thiol biosynthesis and antioxidant machinery. BMC Plant Biol. 2019, 19, 1-16. [CrossRef]

155. Yadu, B.; Chandrakar, V.; Meena, R.K.; Poddar, A.; Keshavkant, S. Spermidine and Melatonin Attenuate Fluoride Toxicity by Regulating Gene Expression of Antioxidants in Cajanus cajan L. J. Plant Growth Regul. 2018, 37, 1113-1126. [CrossRef]

156. Banerjee, A.; Roychoudhury, A. Melatonin application reduces fluoride uptake and toxicity in rice seedlings by altering abscisic acid, gibberellin, auxin and antioxidant homeostasis. Plant Physiol. Biochem. 2019, 145, 164-173. [CrossRef] [PubMed]

157. Kanwar, M.K.; Xie, D.; Yang, C.; Ahammed, G.J.; Qi, Z.; Hasan, K.; Reiter, R.J.; Yu, J.-Q.; Zhou, J. Melatonin promotes metabolism of bisphenol A by enhancing glutathione-dependent detoxification in Solanum lycopersicum L. J. Hazard. Mater. 2020, $388,121727$. [CrossRef] [PubMed] 